UII norden

Food contact materials - metals and alloys

Nordic guidance for authorities, industry and trade

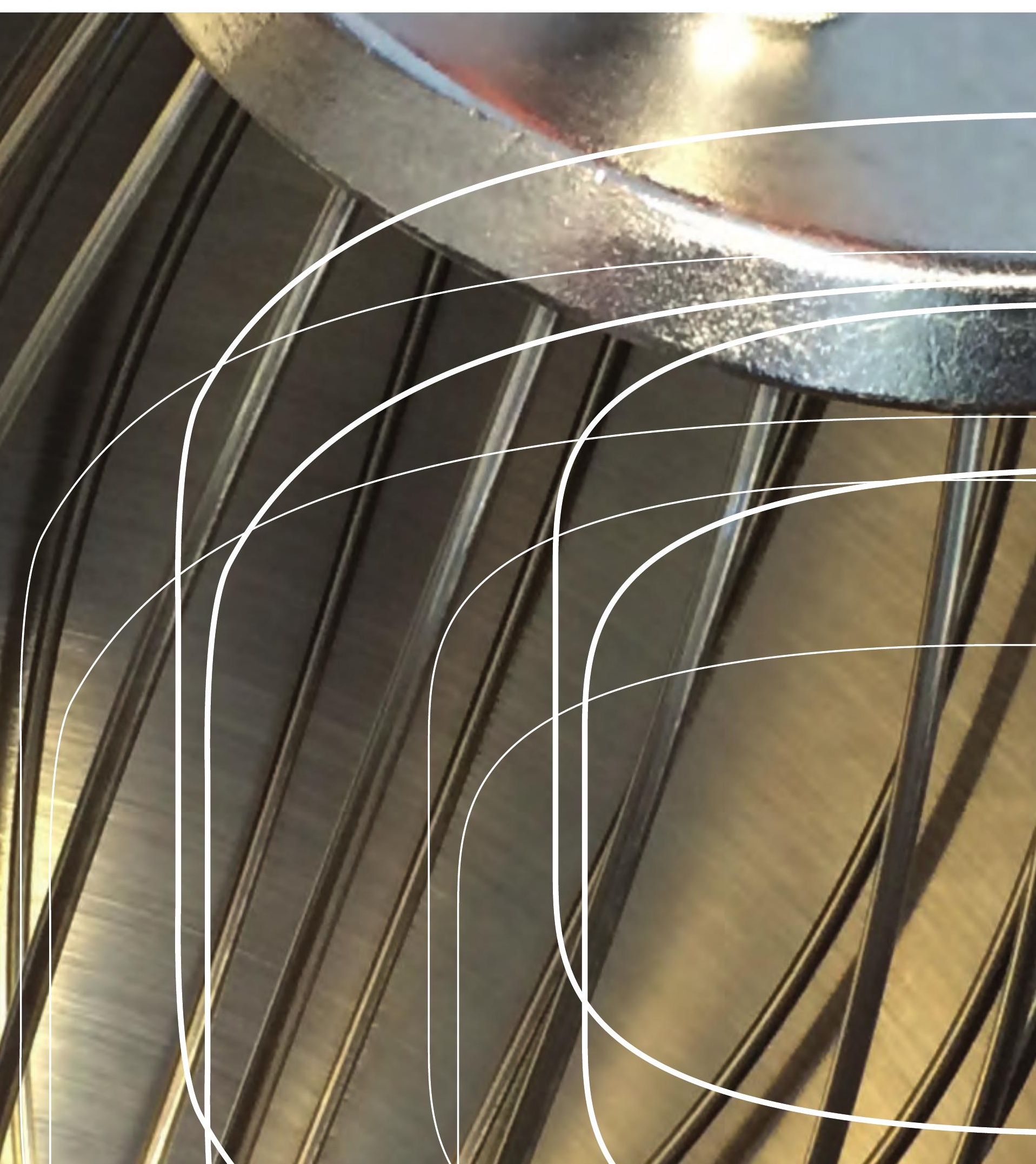



4 norden 



\section{Food contact materials - metals and alloys}

Nordic guidance for authorities, industry and trade

Dorthe Licht Cederberg, Mette Christiansen, Susanne Ekroth, Joakim Engman, Bente Fabech, Katrín Guðjónsdóttir, Julie Tesdal Håland, Ingibjörg Jónsdóttir, Pirkko Kostaomo, Charlotte Legind, Bjørg Mikkelsen, Grímur Ólafsson and Kettil Svensson 
Food contact materials - metals and alloys

Nordic guidance for authorities, industry and trade

Dorthe Licht Cederberg, Mette Christiansen, Susanne Ekroth, Joakim Engman, Bente Fabech, Katrín Guðjónsdóttir, Julie Tesdal Håland, Ingibjörg Jónsdóttir, Pirkko Kostaomo, Charlotte Legind, Bjørg Mikkelsen, Grímur Ólafsson and Kettil Svensson

ISBN 978-92-893-4033-5 (PRINT)

ISBN 978-92-893-4034-2 (PDF)

ISBN 978-92-893-4035-9 (EPUB)

http://dx.doi.org/10.6027/TN2015-522

TemaNord 2015:522

ISSN 0908-6692

(C) Nordic Council of Ministers 2015

Layout: Hanne Lebech

Cover photo: Charlotte Legind

Print: Rosendahls-Schultz Grafisk

Copies: 100

Printed in Denmark

This publication has been published with financial support by the Nordic Council of Ministers. However, the contents of this publication do not necessarily reflect the views, policies or recommendations of the Nordic Council of Ministers.

\section{www.norden.org/en/publications}

Nordic co-operation

Nordic co-operation is one of the world's most extensive forms of regional collaboration, involving Denmark, Finland, Iceland, Norway, Sweden, and the Faroe Islands, Greenland, and Åland.

Nordic co-operation has firm traditions in politics, the economy, and culture. It plays an important role in European and international collaboration, and aims at creating a strong Nordic community in a strong Europe.

Nordic co-operation seeks to safeguard Nordic and regional interests and principles in the global community. Common Nordic values help the region solidify its position as one of the world's most innovative and competitive.

\section{Nordic Council of Ministers}

Ved Stranden 18

DK-1061 Copenhagen K

Phone (+45) 33960200

\section{www.norden.org}




\section{Content}

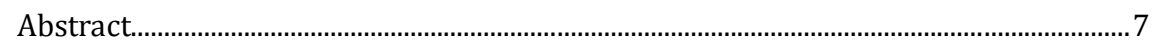

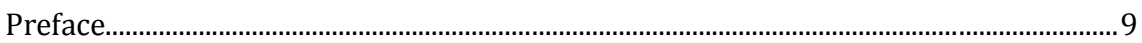

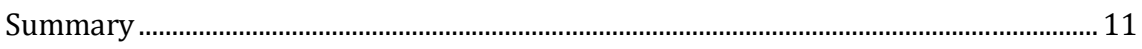

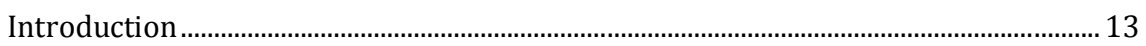

1. Food contact materials: Use of metals and alloys .................................................... 15

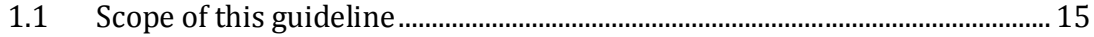

1.2 Food contact materials and metals .................................................................... 16

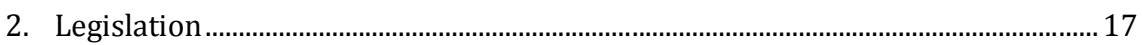

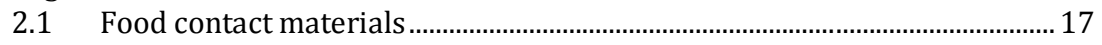

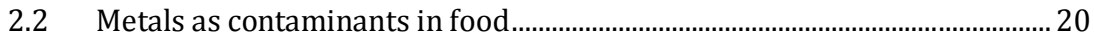

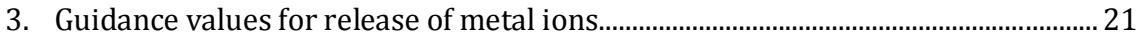

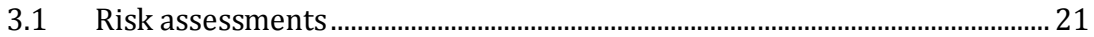

3.2 Setting guidance values.................................................................................. 21

4. Proposals for future work ........................................................................................ 49

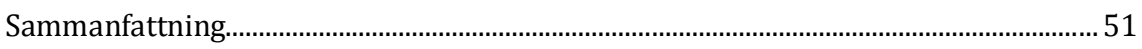

Annex I: Links to legislation and guidance: EU and Nordic webpages ...........................53

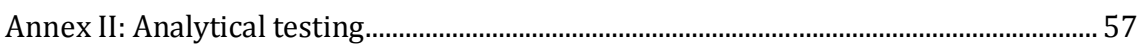

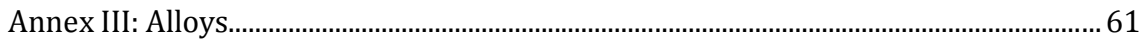





\section{Abstract}

Metals and alloys are widely applied as food contact materials, e.g. as process equipment in the food industry and as household utensils. Therefore, they are a potential source of food contamination. Migration of substances from food contact materials to food must not occur in amounts that endanger human health. Relevant for food contact materials made from metals and alloys are the migration (release) of metals, both the main components and foreseen impurities.

In-house control based on a declaration of compliance, DoC, and supporting documentation at the producers and importers are important prerequisites to limit this contamination and to ensure compliance with the legislation. This is considered a general part of quality assurance, even though the European legislation does not specifically require a DoC for metals and alloys used as food contact materials.

This Nordic guideline gives a short overview of toxicology, analytical feasibility, legislation and guideline values for release of metals from food contact materials. Therefore, the guideline will be a useful tool for industry and official food inspectors.

The guideline is based on the work done by the Council of Europe, risk assessments from the European Food Safety Authority, EFSA, and by the WHO/FAO Joint Expert Committee on Food Additives, JECFA. Additional sources of information on metals in food are the plastic food contact material (EU regulation 10/2011) and the contaminants legislation (EU regulation 1881/2006). 



\section{Preface}

Metals and alloys are widely applied as food contact materials, e.g. as process equipment in the food producing industry. Therefore, they are a potential source of food contamination.

In-house control based on a declaration of compliance, DoC, and supporting documentation at the producers and importers are important prerequisites to limit this contamination and to ensure compliance with the legislation. This is considered a general part of quality assurance, even though the European legislation does not specificly require DoCs for metals and alloys used as food contact materials. Some metallic elements are regulated as contaminants in food, and the maximum levels in this legislation cover metals from all sources, including food contact materials.

The Nordic countries, Denmark, Finland, Iceland, Norway and Sweden, have had trade agreements and have co-operated within numerous areas for many years. Denmark, Finland and Sweden are members of the European Union, and Iceland and Norway are associated through the European Economic Agreement, EEA. For metals and alloys used as food contact materials, the guideline limits for release might differ between the countries. This together with the countries being trade partners creates a call for uniform guidance and interpretations for the metals and alloys used as food contact materials. Guidance on FCM has been given for years from authorities in the Nordic countries, both from the individual countries and by joint work done on check lists in the Nordic Council of Ministers.

The project group consisted of the following persons:

- Denmark

Charlotte Legind, Bente Fabech, Dorthe Licht Cederberg and Mette Christiansen, Danish Veterinary and Food Administration.

- Finland Pirkko Kostamo, Finnish Food Safety Authority Evira.

- Faroe Island Bjørg Mikkelsen, Faroese Food and Veterinary Authority. 
- Iceland

Ingibjörg Jónsdóttir and Katrín Guðjónsdóttir, Icelandic Food and Veterinary Authority.

- Norway

Grímur Ólafsson (chairman) and Julie Tesdal Håland Norwegian Food Safety Authority.

- Sweden

Kettil Svensson and Susanne Ekroth, Swedish National Food Agency.

The Nordic Committee for Nutrition and Toxicology adopted the project which was sponsored by the Nordic Committee of Senior Officials for Food Issues under the Nordic Council of Ministers. 


\section{Summary}

Migration of substances from food contact materials to food must not occur in amounts that endanger human health. Relevant for food contact materials made from metals and alloys are the migration of metals, both the main components and foreseen impurities. To aid industry and national food authorities, the Council of Europe has suggested specific release limits (SRLs) for most metals (Table 1).

Table 1. Overview of the Council of Europe specific release limits (SRLs)

\begin{tabular}{lr} 
Metal & Council of Europe SRL (mg/kg) \\
Aluminium & 5 \\
Antimony & 0.04 \\
Arsenic & 0.002 \\
Barium & 1.2 \\
Beryllium & 0.01 \\
Cadmium & 0.005 \\
Chromium & 0.250 \\
Cobalt & 0.02 \\
Copper & 4 \\
Iron & 40 \\
Lead & 0.010 \\
Lithium & 0.048 \\
Magnesium & $-\mathrm{a}$ \\
Manganese & 1.8 \\
Mercury & 0.003 \\
Molybdenum & 0.12 \\
Nickel & 0.14 \\
Silver & 0.08 \\
Thallium & 0.0001 \\
Tin & 100 \\
Titanium & $-\mathrm{a}$ \\
Vanadium & 0.01 \\
Zinc & 5 \\
\hline
\end{tabular}

${ }^{a}$ Deriving an SRL was found unneccessary.

The outcome of this work is to recommend these values as guideline values for release from food contact materials made of metals and alloys, and to give additional Nordic comments, e.g. concerning toxicology and analytical feasibility. 



\section{Introduction}

The control and documentation of compliance, trade and production of FCMs in the Nordic countries is based on the general requirements in EU regulation 1935/2004 and 2023/2006. One main requirement in regulation 1935/2004 is that FCMs must not release constituents in amounts that can endager human health. To fulfill this requirement a risk assessment of chemical release from FCM to food is needed. However, this can be difficult to perform. Especially for materials which have no detailed regulation, as for metal and alloys. This report is meant to serve as a guidance document to support compliance work in trade and industry, but also as a tool for the official food inspection with regard to FCM composed of metals and alloys.

This guide collates, evaluates and recommends risk based guidance limits for release from metals and alloys used as food contact material. The report is based on the work done by the Council of Europe, risk assessments from the European Food Safety Authority, EFSA, and by the WHO/FAO Joint Expert Committee on Food Additives, JECFA.

Additional sources of information on metals in food are the contaminants legislation (EU regulation 1881/2006). 



\section{Food contact materials: Use of metals and alloys}

Metals and alloys are used as food contact materials, mainly in processing equipment, containers and household utensils but also in e.g. foils for wrapping food where they play a role as a safety barrier between the food and the exterior. Metals and alloys are often covered by a surface coating. When they are not coated these food contact materials can give rise to release of metal ions to the food due to corrosion of the metal. This might endanger human health if the total content of the metals in food exceeds the health based guideline values, if any, or bring about an unacceptable change in the composition of the food or a deterioration of its organoleptic characteristics. Therefore, it was deemed necessary to establish these guidelines to regulate this sector. Also, the Council of Europe has made a report on metals and alloys in 2013.1

This Nordic guideline gives a short overview of toxicology, analytical feasibility, legislation and guideline values for release of metals. Therefore, the guideline will be a useful tool for industry and official food inspectors.

Release of metals occurs due to corrosion of the metal material. As this mechanism differs from migration the correct term concerning metal materials is release instead of migration.

\subsection{Scope of this guideline}

The elements of the periodic system may broadly be divided in three groups: metals, metalloids and non-metals. Metals are the largest group comprising around $80 \%$ of all the elements. Metals can generally be

${ }^{1}$ Council of Europe (2013): Metals and alloys used in food contact materials and articles. A practical guide for manufacturers and regulators. Committee of experts on packaging materials for food and pharmaceutical products. (P-SC-EMB) 1-215. 
characterised on the basis of their chemical and physical properties in the solid state. A pure metal generally:

- is a good conductor of electricity and heat

- shows metallic lustre due to high reflectivity

- is malleable, i.e. it can be pounded into sheets or pressed permanently out of shape without breaking or cracking

- is ductile, i.e. it can be drawn into a thin wire

- can be fused or melted.

Other properties of metals are that they have one to five electrons in the outermost shell, readily form cations, form oxides, hydroxides and binary metal hydrides, and can react with some non-metals usually giving ionic compounds and with other metals forming metallic compounds. ${ }^{2}$ These metallic compounds composed of several metals might be referred to as alloys. Stainless steel is the alloy which is most widely used, and therefore it has a separate description in this guideline in Annex III.

Metalloids fall in between the two categories, since they possess both metallic and non-metallic properties. Examples of these are antimony and arsenic.

This guideline covers the metals and metalloids that are typically used in FCMs or found as impurities in e.g. alloys used in FCM. The elements included are aluminium, antimony, arsenic, barium, beryllium, cadmium, chromium, cobalt, copper, iron, lead, lithium, magnesium, manganese, mercury, molybdenum, nickel, silver, thallium, tin, titanium, vanadium and zinc.

\subsection{Food contact materials and metals}

Metals and alloys are used for many types of food contact materials, most widely for process equipment in the food industry as well as in private households. Some examples of process equipment are storage containers, spray dryers, boilers, kitchen knives, pipes, pots, pans and cutlery as well as industrial food production equipment. Examples of other uses of metals and alloys as FCM are cans, foils and layers in multilayer materials, e.g. a metal layer in plastic packaging.

${ }^{2}$ Holtzclaw et al. (1991) General chemistry. D. C. Heath and Company. 


\section{Legislation}

\subsection{Food contact materials}

The harmonized legislation on food contact materials, FCM, regulation $1935 / 2004$, covers general requirements for all types of FCM. The regulation applies to FCM which:

- "are intended to be brought into contact with food

- are already in contact with food and were intended for that purpose

- can reasonably be expected to be brought into contact with food or to transfer their constituents to food under normal or foreseeable conditions of use."

The legislation on FCMs will not be described in detail in this guideline. An overview of webpages describing the EU and the Nordic legislation on FCM can be found in Annex I.

\subsubsection{EU specific measures and national legislation}

In addition to the general requirements for all types of FCM, EU has specific measures for plastic (virgin and recycled), active and intelligent packaging, ceramics, epoxy derivatives and regenerated cellulose.

Besides the harmonized legislation, some countries, including some of the Nordic countries, have national legislation on release of metals from FCM, e.g from glass and ceramics. Also, Denmark and Norway have requirements for a declaration of compliance, DoC, for all types of materials, including metals, cardboard and paper. The EU regulations on FCM only require a DoC for materials with a specific measure, e.g. plastic.

\subsubsection{Good manufacturing practice, GMP}

Good manufacturing practice, GMP, is required in the production of FCM, as it is in the production of food. GMP comprises quality assurance and identification of critical control points, CCPs, in the manufacturing process. 
For food authorithies, the requirements are included in regulation $882 / 2004$ on official controls, whereas for companies and FCM, they are defined in regulation 2023/2006. Regulation 2023/2006 defines that good manufacturing practice, GMP, "means those aspects of quality assurance which ensure that materials and articles are consistently produced and controlled to ensure conformity with the rules applicable to them and with the quality standards appropriate to their intended use by not endangering human health or causing an unacceptable change in the composition of the food or causing a deterioration in the organoleptic characteristics thereof." Also, it says that quality assurance "means the total sum of the organised and documented arrangements made with the purpose of ensuring that materials and articles are of the quality required to ensure conformity with the rules applicable to them and the quality standards necessary for their intended use."

Guidelines for the application of GMP in the production of some FCMs composed of metals and alloys are given from the Italian authorities, see the CAST project http://www.iss.it/binary/publ/cont/11_37_web.pdf. The CAST guidance document includes examples on e.g. cans, tubes and thin foil.

\subsubsection{Documentation of compliance, DoC}

Compliance with the legislation must be documented as part of the inhouse control in industry and trade. Documentation consists of the declaration of compliance, DoC, and the supporting documentation.

The declaration of compliance is used among trade partners to state that the food contact material complies with the rules applicable to it. Its purpose is to strengthen the coordination and responsibility of the suppliers at each stage of manufacture, including that of the starting substances. This means that the responsible companies must document compliance with the relevant rules and make it available to their customers.

The supporting documentation is the complete documentation of compliance, which contains all details, e.g. on analytical testing methods and detection limits of methods. The supporting documentation can be kept confidential, but should be available for the authorities on request, and it is often used by industry and trade, e.g. when consultants are checking for compliance. Information on migration test (release of metal ions) and analytical methods for metals is found in Annex II of this report.

Used production equipment can present a challenge concerning documentation of compliance, since it can be used for decades and might have parts replaced during this period. For such equipment, relevant 
documentation should generally be stored for 5 years and as long as the equipment is in use. However, compliance must not be documented for used production equipment bought prior to 3rd December 2004, when regulation 1935/2004 went into force. Only, compliance of repairs made after this date, including adding new parts such as e.g. pipes, hoses and gaskets must be documented.

Nordic work on a check list for drafting the declaration of compliance for the final food contact material is on-going. This work is expected to be finalized in 2015 .

\subsubsection{Traceability}

Regulation 1935/2004 sets requirements for traceability in article 17. These requirements went into force in October 2006. All companies along the supply chain are responsible for documenting traceability, i.e. including food producers and producers, importers, distributors and retailers of FCM starting substances, intermediates and final FCM.

Traceability applies to all parts of FCM, including spare parts for production equipment. Traceability should be available from the seller to the buyer - "one step back and one step forward." For example, a sandwich bar shall have documentation and traceability for wrapping and containers used for food contact, and a plastic producer shall include information about the plastic pellet supplier in the documentation for the final FCM.

\subsubsection{Technical properties}

Technical properties of FCM, like e.g. production equipment, are the responsibility of the food producers. When selecting process equipment and other types of FCM composed of metals and alloys, issues like suitability for the specific uses (foods in contact, $\mathrm{pH}$, temperatures, maintenance requirements and hygienic properties) should be taken into account in addition to compliance with the legal requirements on safety and organoleptic inertness. For process equipment, especially the use of disinfectants can be a challenge for some alloys.

The legislation on hygiene of food, regulation 852/2004 sets out requirements for FCM. ${ }^{3}$ Food producers are responsible for hygienic stor-

${ }^{3}$ Especially Annex II, Chapter V, Chapter IX, point 3, and Chapter X. 
age and handling of FCM in order to prevent cross contamination. For metals and alloys, corrosion of the surface will decrease the possibilities of a good hygienic status of the FCM.

Guidance on technical properties are often given by the producers of materials, e.g. the European Stainless Steel Development Association (EuroInox) has published several, informative booklets (http://www.euroinox. com/en/download-0). Also, Annex III of this report contains a short overview of stainless steel, qualities and maintenance.

\subsection{Metals as contaminants in food}

The legislation on contaminants in food, regulation 1881/2006, takes account of the following metals: cadmium, inorganic tin, lead and mercury from all sources, including release from FCM.

Limits for these metals are set in several types of food and furthermore, requirements for sampling, analysis and reporting are attached to this legislation in regulation 333/2007 and have to be taken into account when evaluating potential release from FCM. This can be complicated in the production of FCM as the environmental background contamination of the food ingredients might not be known. However, in general, cadmium, lead and mercury should not be found in FCM. Still, in practice, e.g. lead is often found in recycled glass. 


\section{Guidance values for release of metal ions}

The overview of guidance values for release of metal ions to food are intended to assist official food inspectors, industry and trade in assessing compliance of FCM. However, it is underlined that in the official control, the values should be used as guidance only, and specific FCM exceeding one of the guidance values should be evaluated on a case-bycase basis.

\subsection{Risk assessments}

Generally, guidance values are based on international risk assessments from the European Food Safety Authority, EFSA, and/or the WHO/FAO Joint Expert Committee on Food Additives and Contaminants, JECFA. The EFSA risk assessment reports are accessable via the links given in the tables on the individual metals in chapter 3 . These risk assessment reports can be used as back up for the guidance values. However, they are quite comprehensive and will not be described in detail here.

\subsection{Setting guidance values}

Maximum limits for cadmium, lead, mercury and inorganic tin in some types of food are set in EU regulation 1881/2006 on contaminants. These limits are maximum limits irrespective of the source of the contamination and therefore include release from FCM. As an example, maximum limits for inorganic tin are set for canned food, where the source is release from cans. The limits for tin in canned food vary from 50 to $200 \mathrm{mg} / \mathrm{kg}$.

The scientific risk assessment by EFSA concludes in some cases that a chemical should be regulated in accordance with the "ALARA principle." This means that the content in food should be "As Low As Reasonably Achiveable." Maximum levels for the chemical in food may therefore be based on what is analytically achievable. For example, the limits for lead are in the range from 0.02 to $1.5 \mathrm{mg} / \mathrm{kg}$. For the 
production and use of FCM, the GMP requirements should make sure that the ALARA principle is kept.

In the specific EU-legislation on FCMs made of plastic, regulation 10/2011, specific maximum migration limits for substances are based on the tolerable daily intake, TDI, of the substance and the assumption that a $60 \mathrm{~kg}$ person consumes $1 \mathrm{~kg}$ of packaged food per day. In a few cases, the limits take into account exposure from other sources like e.g. environmental contamination. This is the case for some of the phthalates like e.g DEHP, where only $50 \%$ of the TDI is allocated for calculating the specific maximum limit for migration from FCMs made of plastics. The Council of Europe uses similar considerations for setting specific release limits, SRLs, in their guidance document on metals and alloys. For further information on the values set by the Council of Europe, see the Council of Europe guideline "Metals and alloys used in food contact materials and articles". 4

\subsubsection{General requirements}

FCM composed of metals and alloys are not covered by specific EUlegislation. Therefore the general reguirements of article 3 in regulation $1935 / 2004$ applies when guidance limits for release of metal ions from metals and alloys are set. Article 3 says that:

"materials and articles shall be manufactured in compliance with good manufacturing practice so that, under normal or foreseeable conditions of use, they do not transfer their constituents to food in quantities which could:

- $\quad$ endanger human health

- bring about an unacceptable change in the composition of the food

- $\quad$ bring about a deterioration in the organoleptic characteristics thereof."

\subsubsection{Guidance values for release of metal ions from FCM}

Release of metal ions from alloys should be assessed individually for all elements used in the alloy as release of the single elements.

The following considerations should be made when setting limits for release of metal ions from food contact materials:

${ }^{4}$ Council of Europe (2013): Metals and alloys used in food contact materials and articles. A practical guide for manufacturers and regulators. Committee of experts on packaging materials for food and pharmaceutical products. (P-SC-EMB) 1-215. 
- What is the toxicological reference dose?

EFSA, WHO and JECFA have proposed toxicological reference doses, e.g. a tolerable daily intake, TDI, for several metals occurring in food and FCM.

- How much of the toxicological reference dose should be allocated to intake from migration/release from FCM?

Other sources than FCM, e.g. indoor and outdoor environment contributing to intake of the metal, should be considered. It has in some cases been proposed that $10 \%$ of the toxicological reference dose should be allocated to intake from FCM. Previously, WHO allocated $10 \%$ of the reference dose for setting maximum levels in drinking water; from 2011 WHO suggests allocating $20 \%$ of the reference dose to intake from drinking water. For metals occurring as contaminants in FCM, the Council of Europe typically allocates $10 \%$ of the reference dose, whereas metals occurring as a major component are handled differently.

- Does regulation $1881 / 2006$ set maximum levels in food?

Maximum levels set for certain types of food are legally binding and FCM must comply with this legislation.

- Does regulation 10/2011 set specific migration/release values from FCM made of plastic?

Specific migration/release limits for certain metals from FCM made of plastic set in regulation 10/2011 are typically set by allocating $100 \%$ of the toxicological reference dose to intake from FCM. However, differences between metals, alloys and plastic materials must be taken into account. E.g. metals are prone to acid attack, whereas plastic in general tend to give higher migration when e.g. exposed to fatty food.

- Does the ALARA (as low as reasonably achievable) principle apply and can the migration/release be avoided?

If good manufacturing practice can avoid the migration/release this should be taken into account.

- Is the release of metal from the FCM intentional - e.g. as for tin used as an antioxidant? 
Active and intelligent FCM must comply with regulation 450/2009. This requires that the metal released from the FCM must be risk assessed by EFSA and authorized for use - e.g. as a food additive.

- What is the analytical quantification level in food or food simulants?

Limits must be analytically feasible - i.e. they should be equal to or higher than the analytical quantification limit in food or food simulants.

- Can food simulants be used for migration/release testing?

Food simulants can be used for estimating migration/release, but it can occur that food simulants will not correctly estimate the release of metal ions from FCM to food. Therefore, results from measurements in food will prevail over results from measurements in food simulants. However, background levels of metals in food should be accounted for.

In the following, information on selected metals and metalloids are given, including guideline values for release of metal ions. For further information on the values set by the Council of Europe, see the Council of Europe guideline "Metals and alloys used in food contact materials and articles". 5

${ }^{5}$ Council of Europe (2013): Metals and alloys used in food contact materials and articles. A practical guide for manufacturers and regulators. Committee of experts on packaging materials for food and pharmaceutical products. (P-SC-EMB) 1-215. 


\section{Aluminium (Al) - Main component}

What and where

Aluminium is the third most abundant element in the earths crust and occurs in many minerals. In addition to FCM, aluminium is used in some food additives, especially in colours and also in antiperspirants, which can contribute to the total human exposure to aluminium. Typical dietary intakes range from 0.2 to $1.5 \mathrm{mg} / \mathrm{kg}$ bw/week.

Toxicological

effects

Aluminium is excreted by the kidneys, and only a small amount is absorbed. The tolerable daily intake set by EFSA is based on effects on the developing brain, neuroand embryotoxicity. Some consumers show sensitivity towards aluminium.

Risk assessments

EFSA has in 2008 set a PTWI (provisional tolerable weekly intake) of $1 \mathrm{mg} / \mathrm{kg}$ bw/week. Intake may exceed the PTWI.

http://www.efsa.europa.eu/en/press/news/afc080715.htm

JECFA has in 2011 set a PTWI of $2 \mathrm{mg} / \mathrm{kg}$ bw/week.

Council of Europe

limit value

The Council of Europe has in 2013 set a specific release limit of $5 \mathrm{mg} / \mathrm{kg}$ based on the ALARA principle.

Other limit values

The EU Drinking water directive (98/83) specifies a limit of $200 \mu \mathrm{g} / \mathrm{L}$.

Nordic comments

$10 \%$ of the EFSA PTWI corresponds to $1 \mathrm{mg} / \mathrm{kg}$. However, the natural levels found in food can be high compared to release from food contact materials and complicate a lower release limit.

Analysis

The limit of quantification by ICP-MS is approximately $0.1 \mathrm{mg} / \mathrm{kg}$ in food. Background contamination during analysis is very common.

Aluminium is used for e.g. sauce pans, coffee pots and cans, and it is often a constituent in alloys.

Processed food

Industrially processed foods with food additives containing aluminium.

Recommendations

Storage of acidic, alkaline or salty food, especially as liquids, in uncoated aluminium should be avoided.

Uncoated aluminium should be labelled for users. An example of such a label could be: "User information: do not use this utensil for storage and processing of acidic, alkaline or salty food." 


\section{Antimony (Sb) - Main component}

What and where Antimony is discharged into the air from natural and human activity.

Typical dietary intakes range from 0.03 to $0.06 \mu \mathrm{g} / \mathrm{kg}$ bw/day.

Toxicological Antimony causes reduced body weight gain, food and water intake in experimental

effects animals.

Risk assessments WHO has in 2008 and 2011 set a TDI of $0.006 \mathrm{mg} / \mathrm{kg}$ bw/day

EFSA has in 2004 evaluated antimony trioxide and based on the WHO evaluation proposed a restriction of $0.04 \mathrm{mg} / \mathrm{kg}$ of food as $\mathrm{Sb}$. http://www.efsa.europa.eu/ en/efsajournal/doc/24a.pdf

Council of Europe The Council of Europe has in 2013 set a specific release limit of $0.04 \mathrm{mg} / \mathrm{kg}$ allocating

limit value $10 \%$ of the toxicological reference value set by WHO of $0.36 \mathrm{mg} /$ day and assuming $60 \mathrm{~kg}$ person consuming $1 \mathrm{~kg}$ of foodstuff per day.

Other limit values The European Commission has in 2004 set a specific migration limit, SML, of $0.04 \mathrm{mg} / \mathrm{kg}$ for antimony in plastic food contact materials (regulation 10/2011) European standard EN 610/1995 for tin and tin alloys has set a specific migration limit for antimony of $0.01 \mathrm{mg} / \mathrm{kg}$.

The EU Drinking water directive (98/83) specifies a limit of $5 \mu \mathrm{g} / \mathrm{L}$.

Nordic comments

Analysis

FCM

Raw food
No comments.

The limit of quantification by ICP-MS is approximately $0.001 \mathrm{mg} / \mathrm{kg}$ in food.

Antimony is used in the production of lead, tin and copper alloys, as a pigment in paint, as a fire-proofing agent in textiles and plastic, and as an opacifying agent in glass, ceramic and enamels.

Antimony is found in most food except oils, fats, milk and eggs. Highest levels are found in sugar, meat and fish. 
Arsenic (As) - Impurity

What and where

Arsenic can be found as inorganic or organic bound arsenic. In fish and seafood arsenic is found as organic arsenic, whereas in rice and drinking water, arsenic is found as inorganic arsenic. Harmful effects are related to inorganic arsenic.

Typical dietary intakes of inorganic arsenic range from

0.13 to $1.22 \mathrm{microgram} / \mathrm{kg}$ bw/day.

Toxicological

Inorganic arsenic is carcinogenic in skin, lungs, kidneys and bladder. Acute poisoning

effects causes vomiting, diarrhea with blood and pain in the esophagus and stomach. Organic arsenic is not of health concern.

Risk assessment

JECFA did in 1989 set a provisional tolerable weekly intake (PTWI) of

$15 \mu \mathrm{g} / \mathrm{kg}$ bw/week. In 2009, EFSA evaluated inorganic arsenic and found that there are health concerns at intakes below this and withdrew the PTWI. EFSA found a benchmark dose level, BMDL01, of $0.3-0.8 \mu \mathrm{g} / \mathrm{kg}$ bw/day.

http://www.efsa.europa.eu/en/press/news/contam091022.htm

Council of Europe

limit value

Other limit values

Nordic comments

Analysis

FCM

GMP

Raw food

Processed food
The Council of Europe has in 2013 set a specific release limit of $0.002 \mathrm{mg} / \mathrm{kg}$ allocating $10 \%$ of the toxicological reference value, BMDL01 of $0.0003 \mathrm{mg} / \mathrm{kg}$ bw/day, and assuming a person of $60 \mathrm{~kg}$ consumes $1 \mathrm{~kg}$ of food.

There are no EU maximum limits for arsenic in food. However, there are draft proposed limits for inorganic arsenic in rice and rice products in EU and Codex. The EU Drinking water directive (98/83) specifies a limit of $10 \mu \mathrm{g} / \mathrm{L}$.

No comments.

The limit of quantification for total arsenic by ICP-MS is approximately $0.01 \mathrm{mg} / \mathrm{kg}$ and the limit of quantification of inorganic arsenic by HPLC-ICP-MS is around $0.001 \mathrm{mg} / \mathrm{kg}$ in food.

Arsenic can be found as an impurity in many metals and alloys.

Codex alimentarius discussion paper on arsenic in food

http://www.foedevarestyrelsen.dk/SiteCollectionDocuments/25 PDF_word filer\%20ti 1\%20download/06kontor/Position\%20Paper\%20on\%20arsenic.pdf

Inorganic arsenic is found in drinking water and rice. 


\section{Barium (Ba) - Impurity}

What and where

Barium is found as an impurity in certain metals and alloys.

Typical dietary intakes range from 0.4 to $2.7 \mathrm{mg} /$ person/day.

Toxicological Cardiovascular effects. Increased risk of nephropathy.

effects

Risk assessments

US EPA has set a toxicological reference value RfD of $0.2 \mathrm{mg} / \mathrm{kg}$ bw/day.

The Scientific Committee on Food did in 1996 evaluate barium in relation to natural mineral water and recommended an upper level of $1 \mathrm{mg} / \mathrm{L}$ in natural mineral water

(http://ec.europa.eu/food/fs/sc/oldcomm7/out09 en.html). This opinion is applied for evaluation of monomers used in FCM in 2001 (http://ec.europa.eu/food/fs/sc/scf/out86_en.pdf).

Council of Europe

limit value

The Council of Europe has in 2013 set a specific release limit of $1.2 \mathrm{mg} / \mathrm{kg}$ allocating 10\% of the US EPA toxicological reference value RfD of $0.2 \mathrm{mg} / \mathrm{kg}$ bw/day and assuming a $60 \mathrm{~kg}$ person consuming $1 \mathrm{~kg}$ of foodstuff.

Other limit values The specific migration limit for plastic food contact materials is $1 \mathrm{mg} / \mathrm{kg}$ (regulation 10/2011) The EU Drinking water directive $98 / 83$ specifies no limit.

Nordic comments No comments.

Analysis The limit of quantification by ICP-MS is approximately $0.09 \mathrm{mg} / \mathrm{kg}$ in food.

FCM Barium chloride is used in pigments, lacquer and glass.

Barium chromate is used to colour glass, ceramics and porcelain and as an anti-corrosion pigment for metals.

Barium bromates are used as corrosion inhibitors in low-carbon steels. Also, barium is used in the production of paper, soap, rubber and linoleum. 
Beryllium (Be) - Impurity

What and where Is mainly found in the form of oxides or complex beryllium-aluminium-silicates known as beryls.

The typical dietary intake is estimated to be around $20 \mu \mathrm{g} /$ person/day in Spain.

Toxicological Most information relates to inhalation toxicity.

effects

Risk assessments

The US EPA (1998) recommended a reference dose, RfD, of $0.002 \mathrm{mg} / \mathrm{kg}$ bw/day and also the Concise International Chemical Assessment Documents, CICAD, derived an oral tolerable intake of $0.002 \mathrm{mg} / \mathrm{kg} \mathrm{bw} /$ day.

Council of Europe

limit value

The Council of Europe has in 2013 set a specific release limit of $0.01 \mathrm{mg} / \mathrm{kg}$ allocating 10\% of the tolerable intake of $0.002 \mathrm{mg} / \mathrm{kg}$ bw/day and assuming a $60 \mathrm{~kg}$ person consuming $1 \mathrm{~kg}$ of food.

Other limit values

The EU Drinking water directive (98/83) specifies no limit.

Nordic comments

No comments.

Analysis

The limit of quantification by ICP-MS is approximately $0.007 \mathrm{mg} / \mathrm{kg}$ in food.

FCM

Beryllium is more ductile than steel and is an excellent heat conductor. It is resistant to concentrated nitric acid and it is mainly used as a hardening agent in alloys. Also, it is used for dental prosthesis and it may be found in alloys for moulding plastics and in plumbs, boilers and pipes. Beryllium oxide may be found in ceramics. 
Cadmium (Cd) - Impurity

What and where? Cadmium is a metal which accumulates in certain types of food, e.g. cocoa beans, sunflower seeds and certain mushrooms. Phosphate fertilizers can have high levels of cadmium. Typical dietary intakes range from 2.3 to $5.4 \mu \mathrm{g} / \mathrm{kg}$ bw/week. This is primarily due to consumption of cereal products and vegetables.

Toxicological effects Cadmium accumulates in kidneys and can cause kidney damage.

Risk assessments $\quad$ EFSA has set a provisional tolerable weekly intake (PTWI) of $2.5 \mu \mathrm{g} / \mathrm{kg}$ bw/week. EFSA expressed concern that the margin between the average weekly intake and the PTWI is small and concluded that there is a need to reduce exposure to cadmium at the general population level. http://www.efsa.europa.eu/en/efsajournal/pub/1975.htm

Council of Europe limit The Council of Europe has in 2013 set a specific release limit of $0.005 \mathrm{mg} / \mathrm{kg}$ corresponding value $\quad$ to the limit of drinking water in directive $98 / 83$. This limit corresponds to allocation of $25 \%$ of the TDI of $0.00036 \mathrm{mg} / \mathrm{kg}$ bw/day and assuming a $60 \mathrm{~kg}$ person consuming $1 \mathrm{~kg}$ of foodstuff per day.

Other limit values

EU maximum limits for food are set in regulation 1881/2006

The EU ceramics directive is under revision. New maximum limits for migration are expected to be $0.005 \mathrm{mg} / \mathrm{kg}$.

The EU Drinking water directive (98/83) specifies a limit of $5 \mu \mathrm{g} / \mathrm{L}$.

Finland has a release limit of $0.1 \mathrm{mg} / \mathrm{dm}^{2}$ from FCM.

Norway has a release limit of $0.01 \mathrm{mg} / \mathrm{L}$ or $0.002 \mathrm{mg} / \mathrm{dm}^{2}$.

Nordic comments $\quad 10 \%$ of the EFSA PTWI would result in $0.002 \mathrm{mg} / \mathrm{kg}$.

Analysis

The limit of quantification by ICP-MS is approximately $0.001 \mathrm{mg} / \mathrm{kg}$ in food.

FCM

Pewter can contain cadmium

Raw food

Highest levels are found in kidneys, bivalve molluscs, sunflower seeds and cocoa beans.

Processed food Cadmium accumulates in certain fruit and vegetables, due to uptake by the roots from soil. Therefore, levels are not reduced by washing or peeling.

Cadmium in zink sulphate used as a food supplement or for feed can be a problem.

Recommendation

Pewter should not be used for acidic or salty food. In cases where adornments can be mistak en for food contact materials and have a glazing containing cadmium, they should be labeled e.g.: "Releases cadmium. Should not be used for food or beverages". 


\begin{tabular}{|c|c|}
\hline \multicolumn{2}{|c|}{ Chromium (Cr) - Main component } \\
\hline What and where & $\begin{array}{l}\text { Chromium occurs mainly in its trivalent form in the environment. The hexavalent form } \\
\text { is found as an industrial contaminant. } \\
\text { EFSA estimates (2014) that average dietary intakes of } \mathrm{Cr}(\mathrm{III}) \text { range from } 0.6 \text { to } \\
1.6 \mu \mathrm{g} / \mathrm{kg} \mathrm{bw} / \text { day. }\end{array}$ \\
\hline $\begin{array}{l}\text { Toxicological } \\
\text { effects }\end{array}$ & $\begin{array}{l}\text { The speciation of chromium is of great importance for toxicology. } \mathrm{Cr}(\mathrm{III}) \text { is the most } \\
\text { stable state and is an essential element for humans. } \mathrm{Cr}(\mathrm{VI}) \text { is highly toxic, including } \\
\text { effects such as genotoxicity. Release from food contact materials is expected to } \\
\text { occur as } \mathrm{Cr}(\mathrm{III}) \text {. }\end{array}$ \\
\hline Risk assessments & $\begin{array}{l}\text { EFSA (2014) has set a TDI of } 300 \mu \mathrm{g} / \mathrm{kg} \text { bw/day for chromium (III). } \\
\text { http://www.efsa.europa.eu/en/efsajournal/pub/3595.htm }\end{array}$ \\
\hline $\begin{array}{l}\text { Council of Europe } \\
\text { limit value }\end{array}$ & $\begin{array}{l}\text { The Council of Europe has in } 2013 \text { set a specific release limit of } 0.250 \mathrm{mg} / \mathrm{kg} \text { based on } \\
\text { the WHO maximum level for intake of } 0.250 \mathrm{mg} / \text { person/day and a } 60 \mathrm{~kg} \text { person } \\
\text { consuming } 1 \mathrm{~kg} \text { of food per day. }\end{array}$ \\
\hline Other limit values & $\begin{array}{l}\text { The EU Drinking water directive (98/83) specifies a limit of } 50 \mathrm{\mu g} / \mathrm{L} \text {. } \\
\text { Finland has a release limit of } 2 \mathrm{mg} / \mathrm{dm}^{2} \text { for FCM }\end{array}$ \\
\hline Nordic comments & No comments. \\
\hline Analysis & The limit of quantification by ICP-MS is approximately $0.03 \mathrm{mg} / \mathrm{kg}$ in food. \\
\hline FCM & $\begin{array}{l}\text { Chromium is found in alloys, certain cans and utensils. Also, it is applied as a coating to } \\
\text { protect other metals from corrosion, e.g. in cans it serves to passivate the tin layer. }\end{array}$ \\
\hline Raw food & $\begin{array}{l}\text { Main sources in the diet are cereals, meat, vegetables and white fish. Most types of } \\
\text { food contain less than } 0.1 \mathrm{mg} / \mathrm{kg} \text { of chromium. }\end{array}$ \\
\hline Processed food & Food supplements can contain chromium(III). \\
\hline
\end{tabular}




\begin{tabular}{|c|c|}
\hline \multicolumn{2}{|c|}{ Cobalt (Co) - Main component } \\
\hline What and where & $\begin{array}{l}\text { Cobalt is a rare element. It is used for high-strength alloys and accounts for } 0.05-0.1 \% \\
\text { of certain types of steel. } \\
\text { Typical dietary intakes range from } 0.18 \text { to } 0.31 \mu \mathrm{g} / \mathrm{kg} \text { bw/day. }\end{array}$ \\
\hline $\begin{array}{l}\text { Toxicological } \\
\text { effects }\end{array}$ & $\begin{array}{l}\text { Cobalt is an essential element present in vitamin B12. Cobalt poisoning causes effects } \\
\text { on the heart, blood pressure, abdominal pain, difficulties with breathing and in worst } \\
\text { cases, death. }\end{array}$ \\
\hline Risk assessments & $\begin{array}{l}\text { The Dutch national institute for public health and the environment, RIVM, has in } 2001 \\
\text { set a TDI of } 0.0014 \mathrm{mg} / \mathrm{kg} \text { bw/day. } \\
\text { EFSA has in } 2012 \text { evaluated cobalt compounds in relation to feed. } \\
\text { http://www.efsa.europa.eu/en/efsajournal/doc/2791.pdf }\end{array}$ \\
\hline $\begin{array}{l}\text { Council of Europe } \\
\text { limit value }\end{array}$ & $\begin{array}{l}\text { The Council of Europe has in } 2013 \text { set a specific release limit of } 0.02 \mathrm{mg} / \mathrm{kg} \text { allocating } \\
20 \% \text { of the toxicological reference dose, TDI at } 0.0014 \mathrm{mg} / \mathrm{kg} \mathrm{bw} / \mathrm{day} \text {, and assuming a } \\
60 \mathrm{~kg} \text { person consuming } 1 \mathrm{~kg} \text { of food per day. }\end{array}$ \\
\hline Other limit values & $\begin{array}{l}\text { The European Commission has in } 2003 \text { set a migration limit for cobalt salts of } 0.05 \\
\mathrm{mg} / \mathrm{kg} \text { for plastic food contact materials (regulation 10/2011) based on the RIVM risk } \\
\text { assessment. } \\
\text { The EU Drinking water directive (98/83) specifies no limit. }\end{array}$ \\
\hline Nordic comments & $10 \%$ of the RIVM TDI is $0.01 \mathrm{mg} / \mathrm{kg}$. \\
\hline Analysis & The limit of quantification by ICP-MS is approximately $0.002 \mathrm{mg} / \mathrm{kg}$ in food. \\
\hline FCM & $\begin{array}{l}\text { Cobalt is used in the production of steel, as a blue colour in glass, enamels and ceram- } \\
\text { ics, and to neutralize the yellow tint from iron in glass. } \\
\text { Cobalt oxide is used in enamel coatings on steel to improve the adherence of the } \\
\text { enamel to the metal. }\end{array}$ \\
\hline Raw food & $\begin{array}{l}\text { Cobalt is normally found in very low concentrations in food }(0.01-0.5 \mathrm{mg} / \mathrm{kg}) \text {. It is } \\
\text { common in green leafy vegetables. }\end{array}$ \\
\hline Processed food & Cobalt can occur in food supplements. \\
\hline
\end{tabular}




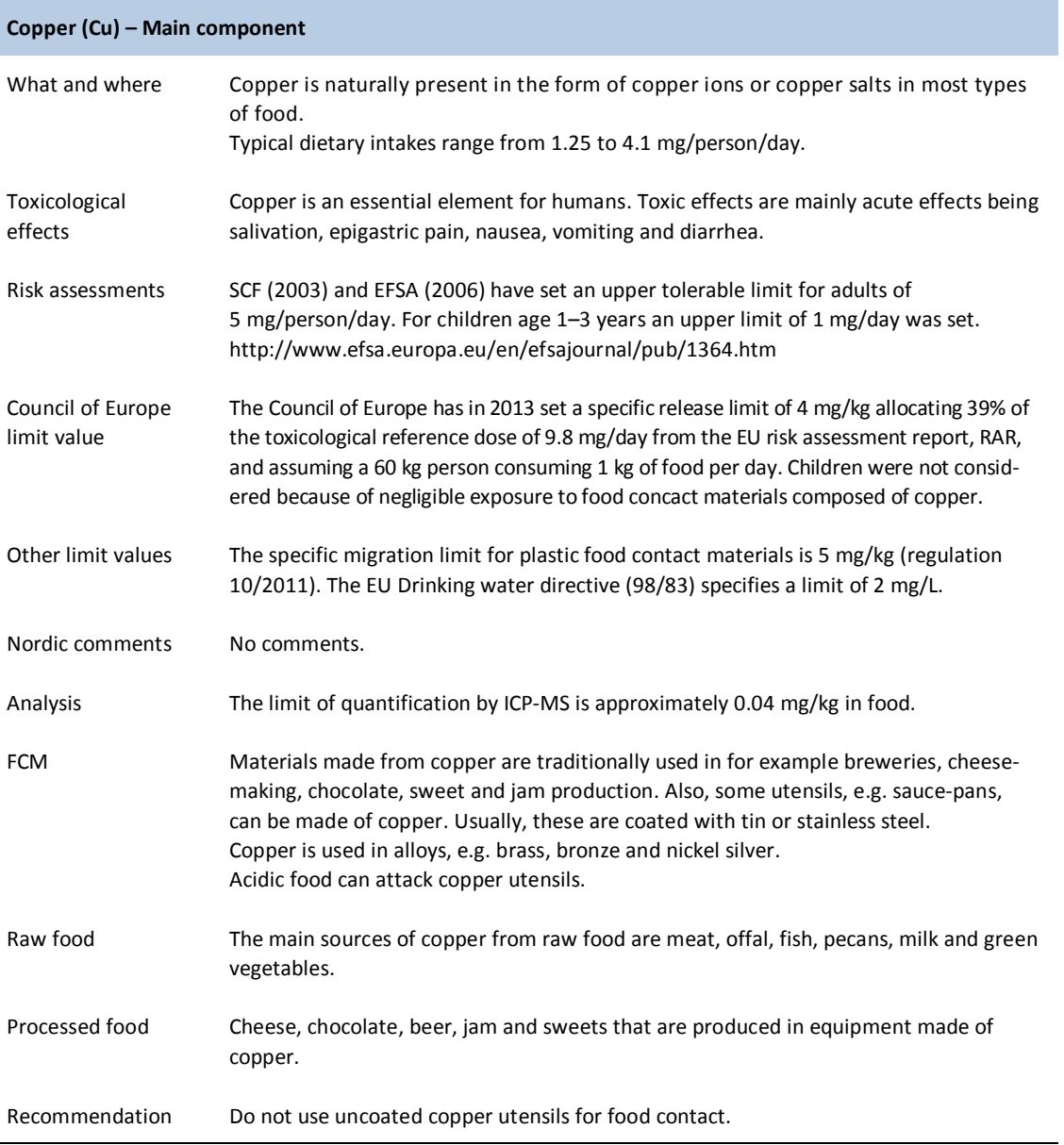




\begin{tabular}{|c|c|}
\hline \multicolumn{2}{|c|}{ Iron (Fe) - Main component } \\
\hline What and where & $\begin{array}{l}\text { Iron is the fourth most abundant element in the earths crust. Iron is present in most } \\
\text { types of food. } \\
\text { Typical dietary intakes range from } 10 \text { to } 72 \mathrm{mg} / \text { person/day. }\end{array}$ \\
\hline $\begin{array}{l}\text { Toxicological } \\
\text { effects }\end{array}$ & $\begin{array}{l}\text { Iron is essential for the synthesis of blood pigments and iron deficiency is a generally } \\
\text { acknowledged problem. } \\
\text { Accidental poisoning with medicinal iron indicates acute damage of gastrointestinal, } \\
\text { hepatic, pancreatic and cardiovascular structures after ingestion of very high doses. An } \\
\text { acute oral dose of } 60 \mathrm{mg} \text { iron/ } \mathrm{kg} \text { bw can be lethal, but oral doses below about 10- } \\
20 \mathrm{mg} \text { iron } / \mathrm{kg} \text { bw do not cause acute systemic toxicity. } \\
\text { Adverse gastrointestinal effects (e.g. nausea, epigastric discomfort, constipation) have } \\
\text { been reported after short-term oral dosage at } 50-60 \mathrm{mg} \text { daily of supplemental non- } \\
\text { haem iron preparations, particularly if taken without food. }\end{array}$ \\
\hline Risk assessments & $\begin{array}{l}\text { JECFA has in } 1983 \text { set a provisional maximum tolerable daily intake, PMTDI, at } \\
0.8 \mathrm{mg} / \mathrm{kg} \text { bw/day. } \\
\text { EFSA has in } 2004 \text { found that data were insufficient to set an upper tolerable limit. } \\
\text { http://www.efsa.europa.eu/en/efsajournal/doc/125.pdf }\end{array}$ \\
\hline $\begin{array}{l}\text { Council of Europe } \\
\text { limit value }\end{array}$ & $\begin{array}{l}\text { The Council of Europe has in } 2013 \text { set a specific release limit of } 40 \mathrm{mg} / \mathrm{kg} \text {, as this level } \\
\text { is reasonably achievable. }\end{array}$ \\
\hline Other limit values & $\begin{array}{l}\text { The specific migration limit for plastic food contact materials is } 48 \mathrm{mg} / \mathrm{kg} \text { (regulation } \\
10 / 2011 \text { ). } \\
\text { The EU Drinking water directive (98/83) specifies a limit of } 200 \mathrm{\mu g} / \mathrm{L} \text { as a technical value. }\end{array}$ \\
\hline Nordic comments & $10 \%$ of the PMTDI corresponds to $4.8 \mathrm{mg} / \mathrm{kg}$. \\
\hline Analysis & The limit of quantification by ICP-MS is approximately $0.1 \mathrm{mg} / \mathrm{kg}$ in food. \\
\hline GMP & $\begin{array}{l}\text { Iron is present in e.g. lids and closures for glass bottles and jars. Also, it is the major } \\
\text { constituent of steel, which is used for e.g. cans, cast iron is used for pots and pans, and } \\
\text { iron oxides are used as paint pigments and for colouring food. } \\
\text { Food contact materials made of iron may release high quantities of iron. }\end{array}$ \\
\hline Raw food & Liver, kidney, beef, ham, egg yolk and soybeans have the highest levels of iron. \\
\hline Processed food & $\begin{array}{l}\text { In some countries, wheat flour is fortified with iron to provide the necessary amount } \\
\text { of iron in the diet. }\end{array}$ \\
\hline
\end{tabular}




\section{Lead $(\mathrm{Pb})-$ Impurity}

What and where?

Lead is a metal, which has previously been used in e.g. petrol, batteries, paint, water pipes and for soldering cans for food. Lead contamination in food originates primarily from airborne contamination, soil or dust. Typically, the highest content is found in fruit and vegetables with a large surface area to volume ratio like e.g. cale and small berries. Typical dietary intakes range from 0.36 to $2.43 \mu \mathrm{g} / \mathrm{kg}$ bw/day.

Toxicological effects Lead influences the nervous system. Especially children are affected as their developing nervous system is sensitive. It affects the intelligence and the ability to learn. Children absorb more lead from food than adults.

Risk assessments EFSA has in 2010 reevaluated the risks of lead. EFSA found that lead was of more toxicological concern than previously assumed. The previously tolerable weekly intake of 25 $\mu \mathrm{g} / \mathrm{kg}$ bw/week was withdrawn, and EFSA suggested that no lower limit for tolerable intake should be set. BMDLs derived from blood lead levels (corresponding dietary intake values) were: developmental neurotoxicity BMDL01, $12 \mu \mathrm{g} / \mathrm{L}(0.50 \mu \mathrm{g} / \mathrm{kg}$ bw/day); effects on systolic blood pressure BMDL01, $36 \mu \mathrm{g} / \mathrm{L}(1.50 \mu \mathrm{g} / \mathrm{kg}$ bw/day); effects on prevalence of chronic kidney disease BMDL10, $15 \mu \mathrm{g} / \mathrm{L}(0.63 \mu \mathrm{g} / \mathrm{kg}$ bw/day). EFSA concluded that it was not possible to exclude a risk to the developing foetus through exposure of pregnant consumers. EFSA recommended that exposure to lead, from both dietary and non-dietary sources, should be reduced. http://www.efsa.europa.eu/en/efsajournal/doc/1570.pdf

Council of Europe limit value

The Council of Europe has in 2013 set a specific release limit of $0.01 \mathrm{mg} / \mathrm{kg}$ corresponding to the limit set in drinking water (directive 98/83). Assuming that a person of $60 \mathrm{~kg}$ consumes $1 \mathrm{~kg}$ of food per day this corresponds to an allocation of $26 \%$ of the toxicological reference value from BMDL10.

Other limit values

EU has maximum limits in food in EU regulation 1881/2006. The levels range from 0.02 to $1.5 \mathrm{mg} / \mathrm{kg}$.

The EU ceramics directive is currently being revised. New maximum limits are expected to be $0.01 \mathrm{mg} / \mathrm{kg}$

The EU Drinking water directive (98/83) specifies a limit of $10 \mu \mathrm{g} / \mathrm{L}$.

Finland has a release limit of $0.5 \mathrm{mg} / \mathrm{dm}^{2}$.

Norway has a release limit of $0.1 \mathrm{mg} / \mathrm{L}$ or $0.02 \mathrm{mg} / \mathrm{dm}^{2}$

Nordic comments

$10 \%$ of the EFSA TDI would result in $0.004 \mathrm{mg} / \mathrm{kg}$.

Analysis

The limit of quantification by ICP-MS is approximately $0.01 \mathrm{mg} / \mathrm{kg}$ in food.

FCM

Lead can be found as an impurity in pewter and tin. Other sources of lead are soldered process equipment, ceramics and printing inks. Also, old water pipes from the first half of the 1900s and before can contain lead. Lead in honey and spices have been traced to originate from process equipment. Recent German and Swedish studies have shown release of lead from certain types of coffee machines.

GMP

Codex Alimentarius has developed a code of practice for prevention and reduction of lead contamination in food (CAC/RCP 56-2004): http://www.codexalimentarius.org/ download/standards/10099/CXP_056e.pdf

Raw food

Intake of lead comes primarily from drinking water, cereal products, vegetables and fruit. Vegetables and fruits with a large surface area to volume ratio have higher levels. Wild game shot with lead bullets can contain considerable levels of lead.

Processed food

Some food supplements and teas can contain considerable amounts of lead.

Recommendation

Do not store port wine or other acidic beverages in crystal glass as crystal glass contain up to $24 \%$ lead. Storage of acidic food in crystal glass will increase the release of lead. Be careful with own import of ceramics, as the glacing on the ceramics may contain lead or cadmium, which can migrate into the food. Products labeled with the glass and fork symbol should not cause any adverse release of lead.

In cases where adornments can be mistaken for food contact materials and has a 


\begin{tabular}{|c|c|}
\hline \multicolumn{2}{|c|}{ Lithium (Li) - Impurity } \\
\hline What and where & $\begin{array}{l}\text { Lithium is widely distributed on earth, but due to its high reactivity it is not in metallic } \\
\text { form, but mainly as an impurity in the salts of other alkali metals. Lithium is the } \\
\text { lightest metal. } \\
\text { Typical dietary intake is around } 20-50 \mu \mathrm{g} / \text { person/day. }\end{array}$ \\
\hline $\begin{array}{l}\text { Toxicological } \\
\text { effects }\end{array}$ & $\begin{array}{l}\text { Lithium salts are used as pharmaceuticals for mood regulation, using the neurological } \\
\text { effects of the ion in the human body. }\end{array}$ \\
\hline Risk assessments & RIVM has in 1991 set a TDI of $0.008 \mathrm{mg} / \mathrm{kg}$ bw/day. \\
\hline Council of Europe & The Council of Europe has in 2013 set a specific release limit of $0.048 \mathrm{mg} / \mathrm{kg}$ allocating \\
\hline limit value & $\begin{array}{l}10 \% \text { of the toxicological reference dose and assuming a } 60 \mathrm{~kg} \text { person consuming } 1 \mathrm{~kg} \\
\text { of food per day. }\end{array}$ \\
\hline Other limit values & $\begin{array}{l}\text { The specific migration limit for plastic food contact materials is } 0.6 \mathrm{mg} / \mathrm{kg} \text { (regulation } \\
10 / 2011 \text { ). } \\
\text { The EU Drinking water directive (98/83) specifies no limit. }\end{array}$ \\
\hline Nordic comments & No comments. \\
\hline Analysis & The limit of quantification by ICP-MS is approximately $0.006 \mathrm{mg} / \mathrm{kg}$ in food. \\
\hline FCM & $\begin{array}{l}\text { Lithium is used in alloys for high quality mechanical parts and in low termal-expansion } \\
\text { glasses and ceramics. }\end{array}$ \\
\hline Raw food & $\begin{array}{l}\text { It can be found in food in concentrations ranging from } 0.012-3.4 \mathrm{mg} / \mathrm{kg} \text {. Main contrib- } \\
\text { utor to intake is water. }\end{array}$ \\
\hline
\end{tabular}




\begin{tabular}{|c|c|}
\hline \multicolumn{2}{|c|}{ Magnesium (Mg) - Main component } \\
\hline What and where & $\begin{array}{l}\text { Magnesium is the eigth most abundant element in the earths crust and magnesium salts are } \\
\text { very abundant in sea water. } \\
\text { Typical dietary intakes are around } 300 \mathrm{mg} / \text { person/day. }\end{array}$ \\
\hline $\begin{array}{l}\text { Toxicological } \\
\text { effects }\end{array}$ & $\begin{array}{l}\text { Magnesium is an essential element for humans. Intake of large quantities causes diarrhea. } \\
\text { Poisoning can occur in children and in cases of renal insufficiency. }\end{array}$ \\
\hline Risk assessments & $\begin{array}{l}\text { SCF has in } 2001 \text { set an upper tolerable limit of } 250 \mathrm{mg} / \text { day for readily dissociable magnesium salts in } \\
\text { nutritional supplements. This upper limit does not include magnesium normally present in food and } \\
\text { beverages (http://ec.europa.eu/food/fs/sc/scf/out105_en.pdf) }\end{array}$ \\
\hline $\begin{array}{l}\text { Council of Europe } \\
\text { limit value }\end{array}$ & $\begin{array}{l}\text { The Council of Europe has in } 2013 \text { decided not to set a specific release limit as adverse effects } \\
\text { due to release from food contact materials are unlikely. }\end{array}$ \\
\hline Other limit values & The EU Drinking water directive (98/83) specifies no limit. \\
\hline Nordic comments & $\begin{array}{l}\text { Release of magnesium will normally be much lower than the levels found naturally in food. A } \\
\text { guidance value for release is therefore not needed. }\end{array}$ \\
\hline Analysis & The limit of quantification by ICP-MS is approximately $0.5 \mathrm{mg} / \mathrm{kg}$ in food. \\
\hline FCM & Magnesium is mainly used in aluminium-magnesium alloys used for beverage cans. \\
\hline Raw food & Seafood has the highest levels of magnesium followed by cocoa and whole grains. \\
\hline
\end{tabular}




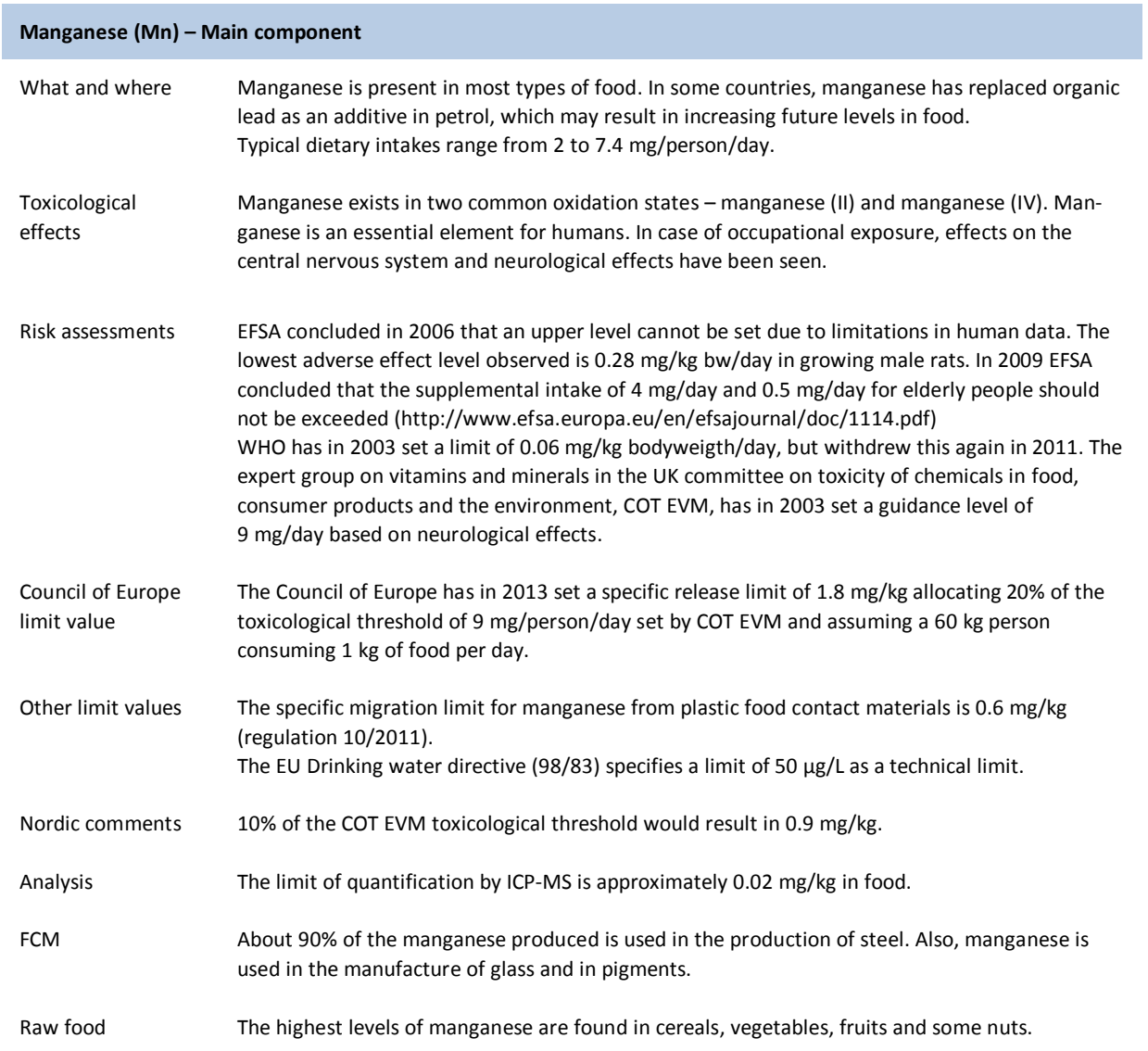




\section{Mercury (Hg) - Impurity}

What and where?

Mercury contamination originates primarily from vulcanic and industrial activity. Mercury accumulates in the food chain with the highest levels being present in big predatory fish such as swordfish, tuna and marine mammals. Also, in certain areas fresh water fish may contain high levels.

Typical dietary intakes range from 0.02 to $0.13 \mu \mathrm{g} / \mathrm{kg}$ bw/day

Toxicological effects

The most sensitive organ is the developing brain of fetuses and small children. Mercury is toxic to the nervous system and causes a risk for slow brain development and learning for children. Methyl mercury is considered one of the most dangerous chemicals for humans.

Risk assessments

EFSA has in 2012 set a tolerable weekly intake (TWI) for methylmercury at $1.3 \mu \mathrm{g} / \mathrm{kg}$ bw/week expressed as mercury. http://www.efsa.europa.eu/en/search/doc/2985.pdf

Council of Europe limit

value

The Council of Europe has in 2013 set a specific release limit for mercury at $0.003 \mathrm{mg} / \mathrm{kg}$ allocating $10 \%$ of the toxicological safety limit of JECFA of $0.004 \mathrm{mg} / \mathrm{kg}$ bw/week and assuming that a $60 \mathrm{~kg}$ person consumes $1 \mathrm{~kg}$ of food.

Other limit values

EU maximum limits for mercury in fish and fishery products have been set in regulation $1881 / 2006$. The levels vary between 0.5 and $1.0 \mathrm{mg} / \mathrm{kg}$

For vegetables, fruits and meat EU maximum levels are set in the legislation for pesticide residues (regulation 396/2005)

The EU drinking water directive (98/83) specifies a limit of $1.0 \mu \mathrm{g} / \mathrm{L}$.

Nordic comments No comments.

Analysis

The limit of quantification by ICP-MS is approximately $0.01 \mathrm{mg} / \mathrm{kg}$ in food.

FCM

Mercury has no known use in food contact materials.

Mercury forms alloys, amalgam, with almost all other metals except iron. One example is dental amalgam, which contains tin and silver dissolved in mercury. Dental amalgam is banned in Denmark, Norway and Sweden and the use is discouraged in the other EU countries.

Raw food

Mercury is primarily present in fish and fishery products as methyl mercury.

High levels of mercury have also been seen in ducks and pigeons shot in areas with a hot spot contamination.

Processed food

Mercury is bound to the protein fraction. For this reason fish oils normally have low levels of mercury. 


\begin{tabular}{|c|c|}
\hline What and where & $\begin{array}{l}\text { Molybdenum is found in most animals and plants. } \\
\text { Typical dietary intakes range from } 89 \text { to } 500 \mu \mathrm{g} / \text { person/day. }\end{array}$ \\
\hline $\begin{array}{l}\text { Toxicological } \\
\text { effects }\end{array}$ & Molybdenum affects growth. \\
\hline Risk assessments & $\begin{array}{l}\text { EFSA has in } 2006 \text { set an upper tolerable limit of } 0.6 \mathrm{mg} / \mathrm{day} \text { for adults and } 0.1 \mathrm{mg} / \mathrm{kg} \\
\text { for children aged } 1-3 \text { years (http://ec.europa.eu/food/fs/sc/scf/out } 80 \mathrm{~h} \text { en.pdf). EFSA } \\
\text { has in } 2013 \text { proposed an adequate intake, Al, value of } 65 \mu \mathrm{gg} / \text { day for adults } \\
\text { (http://www.efsa.europa.eu/en/efsajournal/pub/3333.htm) }\end{array}$ \\
\hline Council of Europe & The Council of Europe has in 2013 set a specific release limit of $0.12 \mathrm{mg} / \mathrm{kg}$ allocating \\
\hline limit value & $\begin{array}{l}20 \% \text { of the toxicological safety limit from EFSA of } 0.6 \mathrm{mg} / \mathrm{day} \text { and assuming a person of } \\
60 \mathrm{~kg} \text { consuming } 1 \mathrm{~kg} \text { of food per day. }\end{array}$ \\
\hline Other limit values & The EU drinking water directive (98/83) specifies no limit. \\
\hline Nordic comments & $10 \%$ of the EFSA TDI corresponds to $0.06 \mathrm{mg} / \mathrm{kg}$. \\
\hline Analysis & The limit of quantification by ICP-MS is approximately $0.006 \mathrm{mg} / \mathrm{kg}$ in food. \\
\hline FCM & $\begin{array}{l}\text { Molybdenum is used in high resistance alloys and high temperature steels. } \\
\text { Molybdenum oxides are used in pigments for ceramics. }\end{array}$ \\
\hline Raw food & $\begin{array}{l}\text { Molybdenum is found in liver, peas, beans, spinach, wheat germ, tomatoes and } \\
\text { lemons. }\end{array}$ \\
\hline
\end{tabular}


Nickel (Ni) - Main component

What and where Nickel can be found in all soils and is emitted from volcanoes. Nickel is widely used for alloys and in plating.

Typical dietary intakes range from 1.49 to $3.83 \mu \mathrm{g} / \mathrm{kg}$ bw/day.

Toxicological

effects

Nickel intake from food causes problems to approximately $10-15 \%$ of the population, mainly women, with nickel allergy. These consumers get flare-up eczema from oral ingestion of even small amounts of nickel. The main targets for the toxicity of orally ingested nickel salts are kidneys, spleen, lungs, and the myeloid system. There is evidence that nickel is carcinogenic by inhalation.

Risk assessments

WHO has in 2008 and 2011 set a TDI of $0.012 \mathrm{mg} / \mathrm{kg}$ bw/day.

EFSA concluded in 2005 that a tolerable upper intake limit could not be set due to inadequate data for dermal reactions. http://www.efsa.europa.eu/en/efsajournal/ pub/146.htm

Council of Europe

limit value

The Council of Europe has in 2013 set a specific release limit of $0.14 \mathrm{mg} / \mathrm{kg}$ allocating $20 \%$ of the TDI of $0.012 \mathrm{mg} / \mathrm{kg}$ bw/day set by WHO and assuming a $60 \mathrm{~kg}$ person consuming $1 \mathrm{~kg}$ of food per day.

Other limit values The EU drinking water directive (98/83) specifies a limit of $20 \mu \mathrm{g} / \mathrm{L}$ as a technical value. Finland has a release limit of $2 \mathrm{mg} / \mathrm{dm}^{2}$ from FCM

Nordic comments $\quad 10 \%$ of the WHO TDI corresponds to $0.07 \mathrm{mg} / \mathrm{kg}$.

Analysis The limit of quantification by ICP-MS is approximately $0.06 \mathrm{mg} / \mathrm{kg}$ in food.

FCM

The major use of nickel is in the production of high quality, corrosion resistant alloys with iron, copper, aluminium, chromium, zinc and molybdenum. Nickel containing stainless steels is used for e.g. process equipment, cook ware, milk and wine tanks. Nickel plated items are less durable and corrosion resistant than stainless steels and therefore not commonly used for articles in contact with food.

Nickel oxide is used for enamel frits and in ceramic glases. Nickel carbonate is used for colouring ceramics and in glazes.

Nickel is present in small quantities in all types of food, but at higher levels in grains, nuts, cocoa and seeds. 


\begin{tabular}{|c|c|}
\hline \multicolumn{2}{|c|}{ Silver (Ag) - Main component } \\
\hline What and where & $\begin{array}{l}\text { Silver is used for dental fillings, and silver salts can be used for e.g. disinfection of } \\
\text { drinking water. Also, silver is used as colouring agent for decorations in confectionary } \\
\text { and in alcoholic beverages. } \\
\text { Typical dietary intakes range from } 1.29 \text { to } 3.47 \mu \mathrm{g} / \mathrm{kg} \text { bw/day. }\end{array}$ \\
\hline $\begin{array}{l}\text { Toxicological } \\
\text { effects }\end{array}$ & $\begin{array}{l}\text { Repeated exposure to silver may result in anaemia, cardiac enlargement, growth } \\
\text { retardation and degenerative changes of the liver. }\end{array}$ \\
\hline Risk assessments & $\begin{array}{l}\text { The European Commission has in } 2005 \text { set a group restriction for migration for sub- } \\
\text { stances containing silver at } 0.05 \mathrm{mg} / \mathrm{kg} \text { food based on a WHO limit of } \\
0.39 \mathrm{mg} / \text { person/day from } 2008 \text { and } 2011 \text {. } \\
\text { http://www.efsa.europa.eu/en/efsajournal/doc/201a.pdf } \\
\text { Food contact materials containing nanoscale silver have not been considered and must } \\
\text { be evaluated separately on a case by case basis. }\end{array}$ \\
\hline $\begin{array}{l}\text { Council of Europe } \\
\text { limit value }\end{array}$ & $\begin{array}{l}\text { The Council of Europe has in } 2013 \text { set a specific release limit of } 0.08 \mathrm{mg} / \mathrm{kg} \text {. This value } \\
\text { is based on intake data from ANSES from } 2011 \text { of } 1.29 \mu \mathrm{g} / \mathrm{kg} \text { bw/day and assuming a } \\
\text { person of } 60 \mathrm{~kg} \text { consumes } 1 \mathrm{~kg} \text { of food per day. }\end{array}$ \\
\hline Other limit values & $\begin{array}{l}\text { Silver is used as a food additive (E174). } \\
\text { The EU drinking water directive (98/83) specifies no limit. }\end{array}$ \\
\hline Nordic comments & No comments. \\
\hline Analysis & The limit of quantification by ICP-MS is approximately $0.08 \mathrm{mg} / \mathrm{kg}$ in food. \\
\hline FCM & $\begin{array}{l}\text { Silver alloyed with } 7.5 \% \text { copper is known as sterling silver. Silver is used in the produc- } \\
\text { tion of cutlery and table ware. }\end{array}$ \\
\hline Processed food & It is applied in colouring agents in decorations for confectionery and alcoholic beverages. \\
\hline
\end{tabular}


Thallium (TI) - Impurity

What and where

Thallium is found in zinc, copper, iron and lead ores and as an impurity in alloys.

Compounds containing thallium are colorless, odorless and tasteless. Thallium salts are used in rodent and insect poisons in some parts of the world.

Typical dietary intake range from $0.01 \mu \mathrm{g} / \mathrm{kg}$ bw/day to $0.02 \mu \mathrm{g} / \mathrm{kg}$ bw/day.

Toxicological

effects

Studies with people who ingested large amounts of thallium over a short period of

time have reported vomiting, diarrhea, temporary hair loss and effects on the nervous system, lungs, heart, liver, and kidneys.

Risk assessments

The US EPA has set a RfD of $0.01 \mu \mathrm{g} / \mathrm{kg}$ bw (2009).

Council of Europe

limit value

The Council of Europe has in 2013 set a specific release limit of $0.0001 \mathrm{mg} / \mathrm{kg}$ allocating $10 \%$ of the toxicological reference dose and assuming a $60 \mathrm{~kg}$ person consuming $1 \mathrm{~kg}$ of food.

Other limit values

French law has set a maximum limit of $0.05 \%$ for the content of thallium in food contact materials.

The EU drinking water directive (98/83) specifies no limit.

Nordic comments

No comments.

Analysis

The limit of quantification by ICP-MS is approximately $0.0002 \mathrm{mg} / \mathrm{kg}$ in food

FCM

Thallium is used in the electronics industry, the pharmaceutical industry and in glass manufacturing. 


\begin{abstract}
Tin (Sn) - Main component
What and where? Tinplate is used in steel cans, from where it can migrate slowly into the food. For some types of foods with a light colour, e.g. asparagus and pineapple, it acts as an antioxidant. Typical dietary intakes range from 23 to $82 \mu \mathrm{g} / \mathrm{kg}$ bw/day.

Toxicological effects Intake of tin causes diarrhea and vomiting. The effect depends on the concentration of Risk assessments tin in the food rather than on the intake per $\mathrm{kg}$ of bodyweight.

Risk assessments

JECFA has set a tolerable weekly intake at $14 \mathrm{mg} / \mathrm{kg}$ bw/week. JECFA has stated that levels of $150 \mathrm{mg} / \mathrm{kg}$ in canned beverages and $250 \mathrm{mg} / \mathrm{kg}$ in other canned types of food can cause acute effects.
\end{abstract}

Council of Europe

limit value

The Council of Europe has in 2013 set a specific release limit of $100 \mathrm{mg} / \mathrm{kg}$ in approximation with the EU maximum limits in regulation 1881/2006.

Other limit values Limits have been set for tin canned food in EU regulation 1881/2006. The limits are $200 \mathrm{mg} / \mathrm{kg}$ for canned food other than beverages; $100 \mathrm{mg} / \mathrm{kg}$ for canned beverages and $50 \mathrm{mg} / \mathrm{kg}$ for canned food for babies, small children and dietary foods for special medical purposes for infants.

The EU drinking water directive (98/83) specifies no limit.

Nordic comments No comments.

Analysis The limit of quantification by ICP-MS is approximately $0.003 \mathrm{mg} / \mathrm{kg}$ in food.

GMP

Codex Alimentarius has made a code of practice for prevention and reduction of inorganic tin in canned food (CAC/RCP 60-2005): http://www.codexalimentarius.org/ download/standards/10217/CXP_060e.pdf

Process conditions: Oxygen and high temperatures can increase the release of tin. Cans should be cooled quickly to 35-40 degrees. The shelflife of the canned food influence the release of tin. The headspace (airspace above the food inside the can) should be minimized. Sealing of the can with vacuum can minimise the levels of oxygen and thereby also the release of tin.

Storage: For each 10 degrees increase in storage temperature the speed of release will double. Therefore, low storage temperatures are preferred.

Choice of materials: Products should comply with standard specifications, e.g. ASTM and ISO.

Tinplate is used in steel cans.

Raw food Especially fruit and vegetables (with a low $\mathrm{pH}$ ) can increase the release of tin.

Processed food Low $\mathrm{pH}$ and corrosion accelerators, e.g. nitrate, increase the release of tin. Low quality of tinplated cans for e.g. pineapple can be a problem.

Recommendation Do not store food in open cans, because opening the can will break the lacquer sealing. This causes direct contact between food and metals in the can. Also, oxygen will increase the release of tin from the can. 


\section{Titanium (Ti) - Main component}

What and where Titanium is the ninth most common element in the earths crust. Titanium is used as colour additive in a broad variety of products, e.g. confectionary, dairy products, soft drinks, inks, toothpaste and pharmaceuticals.

Typical dietary intakes range from 0.3 to $1 \mathrm{mg} /$ person/day.

Toxicological Titanium seems to be practically inert, i.e. it will pass through the human body. How-

effects

ever, it is estimated that $0.8 \mathrm{mg} /$ day will be absorbed.

Risk assessments JECFA did in 1969 not set an ADI for titanium oxide due to lack of significant absorption and storage. EFSA concurred with this in 2005.

http://www.efsa.europa.eu/en/efsajournal/pub/163.htm

Council of Europe The Council of Europe has in 2013 decided not to set a specific release limit as titanium

limit value is considered to be practically inert.

Other limit values

The EU drinking water directive (98/83) specifies no limit.

Nordic comments

No comments.

Analysis

No information

FCM

Stainless steel can contain up to $1 \%$ titanium.

Titanium oxide is used in white pigments in e.g. paints, lacquers, enamels, paper coatings and plastics. Titanium oxide is used as a food additive. 


\begin{tabular}{|c|c|}
\hline \multicolumn{2}{|c|}{ Vanadium (V) - Main component } \\
\hline What and where & $\begin{array}{l}\text { More than } 80 \% \text { of the world's production of vanadium is used in steel for tools and } \\
\text { surgery equipment and in alloys such as ferrovanadium. Vanadium is used in ceramic } \\
\text { pigments and in pharmaceuticals. It has a good corrosion resistance against alkalis, } \\
\text { sulphuric acid, hydrochloric acid and salt water. } \\
\text { Typical dietary intakes range from } 6 \text { to } 156 \mu \mathrm{g} / \text { person/day. }\end{array}$ \\
\hline $\begin{array}{l}\text { Toxicological } \\
\text { effects }\end{array}$ & $\begin{array}{l}\text { Vanadium gives adverse effects on kidneys, spleen, lungs and blood pressure. Deve- } \\
\text { lopmental toxicity has been observed in rats. }\end{array}$ \\
\hline Risk assessments & $\begin{array}{l}\text { The European Medicines Agency, EMA, found a human NOEL of } 0.5 \mathrm{mg} / \mathrm{kg} / \mathrm{day} \text {. } \\
\text { EFSA found in } 2004 \text { and } 2009 \text { that an exposure of } 0.01 \text { to } 0.02 \mathrm{mg} / \mathrm{day} \text { is at least three } \\
\text { orders of magnitude below the dose which causes gastrointestinal effects in body } \\
\text { builders taking vanadium as supplements. http://www.efsa.europa.eu/en/press/ } \\
\text { news/afc080226.htm }\end{array}$ \\
\hline $\begin{array}{l}\text { Council of Europe } \\
\text { limit value }\end{array}$ & $\begin{array}{l}\text { The Council of Europe has in } 2013 \text { set a specific release limit of } 0.01 \mathrm{mg} / \mathrm{kg} \text { using the } \\
\text { value of } 0.01 \mathrm{mg} / \text { day set by EFSA and assuming a } 60 \mathrm{~kg} \text { person consuming } 1 \mathrm{~kg} \text { of food } \\
\text { per day. }\end{array}$ \\
\hline Other limit values & The EU drinking water directive (98/83) specifies no limit. \\
\hline Nordic comments & No comments. \\
\hline Analysis & The limit of quantification by ICP-MS is approximately $0.02 \mathrm{mg} / \mathrm{kg}$ in food. \\
\hline FCM & $\begin{array}{l}\text { Vanadium alloys can be used to manufacture different tools, e.g. adding approximately } \\
1 \% \text { of vanadium to steel produces a highly shock-resistant alloy. Vanadium steel is } \\
\text { used for e.g. axes, knives and spare parts for rotating machines. } \\
\text { Vanadium is used in ceramics and glass pigments with blue and green colours. }\end{array}$ \\
\hline Raw food & $\begin{array}{l}\text { Mainly found in seafood and mushrooms, but also in many fruits and vegetables in } \\
\text { very low amounts. }\end{array}$ \\
\hline
\end{tabular}




\section{Zinc (Zn) - Main component}

What and where

Zinc is an essential trace element and occurs in most types of food and beverages. Typical dietary intakes range from 8 to $16 \mathrm{mg} /$ person/day.

Toxicological Zinc is not stored in the body and excess intakes result in reduced absorption and effects increased excretion. Nevertheless, cases of zinc poisoning have been reported -e.8. from galvanised iron containers holding acidic drinks. Symptoms of acute effects include nausea, vomiting, epigastric pain, abdominal cramps and diarrhoea, whereas chronic toxicity are linked to increased copper excretion and decreased copper retention.

Risk assessment

The scientific committee on food has in 2003 set an upper limit for zinc at $25 \mathrm{mg} / \mathrm{day}$ for adults and $7 \mathrm{mg} /$ day for children aged 1-3 years, based on effects on the coppe balance as a critical endpoint (http://ec.europa.eu/food/fs/sc/scf/out177_en.pdf). EFSA concluded in 2014 that zinc contributes to normal function of the immune system (http://www.efsa.europa.eu/en/efsajournal/pub/3653.htm)

Council of Europe

limit value

Other limit values

Nordic comments

Analysis

FCM

Raw food

Processed food

The Council of Europe has in 2013 set a specific release limit of $5 \mathrm{mg} / \mathrm{kg}$ allocating 20\% of the toxicological threshold from EFSA at $25 \mathrm{mg} /$ day and assuming a $60 \mathrm{~kg}$ person consuming $1 \mathrm{~kg}$ of food per day.

The specific migration limit for plastic food contact materials is $25 \mathrm{mg} / \mathrm{kg}$ (regulation 10/2011)

The EU drinking water directive (98/83) specifies no limit.

$10 \%$ of the EFSA upper tolerable limit corresponds to $2.5 \mathrm{mg} / \mathrm{kg}$

The limit of quantification by ICP-MS is approximately $0.1 \mathrm{mg} / \mathrm{kg}$ in food.

The most important use of zinc is in galvanised iron. Zinc protects iron from rusting because it is a stronger reducing agent. Also, zinc is used in alloys such as brass and bronze.

Zinc coated steels are used in silos for storing food.

Zinc sulphide and zinc oxide are used for paints, ceramics and other products. Zinc may contain small amounts of cadmium and lead as impurities.

The main contributors to zinc intake are meat, whole grain cereals and milk products like cheese. Also, oysters and peanuts contain high levels of zinc.

Cheese

Do not use galvanised iron for contact with liquid or moist food. 



\section{Proposals for future work}

For some metals knowledge on actual release of metal ions is limited. The guidance release values are to a large extent based on theoretical estimations and calculations based on toxicological threshold values, but lower limits could possibly be achievable.

Many metal food contact materials are coated - like aluminium frying pans coated with the fluoropolymer Teflon ${ }^{\circledR}$ (PTFE). Knowledge on impurities in the metals used and release when the coating is no longer intact is limited.

Industry develops new materials all the time. More knowledge on release of metal ions from these materials is required for evaluation of the safety. 



\section{Sammanfattning}

Metaller och legeringar används i stor utsträckning som material i kontakt med livsmedel, t.ex. som processutrustning inom livsmedelsindustrin och som husgeråd. Dessa är därför en möjlig källa till förorening av livsmedel. Migration av ämnen från material i kontakt med livsmedel får inte förekomma i mängder som kan vara skadligt för människors hälsa. För material tillverkade av metall eller som legering är migrationen (utlösningen) av metallen själv, eller som förorening av betydelse.

Egenkontroll baserad på en förklaring om överensstämmelse (declaration of compliance; DoC) och underlag från producenter och importörer är viktiga förutsättningar för att begränsa mängden föroreningar och för att säkerställa att lagstiftningen efterlevs. Detta är ett allmänt krav i kvalitetssäkringen trots att EU-lagstiftningen inte uttryckligen kräver en förklaring om överensstämmelse (DoC) för material av metall eller som legering i kontakt med livsmedel.

Denna nordiska vägledning ger en kort översikt av toxikologi, analytisk genomförbarhet, lagstiftning och riktvärden för utlösning av metaller från material i kontakt med livsmedel. Vägledningen kommer därför att bli ett användbart verktyg för industri och livsmedelsinspektörer.

Vägledningen är baserad på Europarådets arbete, riskbedömningar från Europeiska myndigheten för livsmedelssäkerhet, EFSA, och WHO/FAOs Joint Expert Committee on Food Additives, JECFA. Andra informationskällor om metaller i livsmedel som använts är lagstiftningen om plast i kontakt med livsmedel (EU-förordning 10/2011) och lagstiftningen om föroreningar i livsmedel (EU-förordning 1881/2006). 



\section{Annex I: \\ Links to legislation and guidance: EU and Nordic webpages}

\section{Legislation}

For food contact materials and articles the general legislation is relevant for the evaluation of metals and alloys. However, in some FCM like process equipment spare parts can be made of other materials like e.g., plastics. In the following the entire list of EU legislation relevant for FCM is included:

- Regulation EC 1935/2004 on materials and articles intended to come into contact with food.

- Regulation EC 2023/2006 on good manufacturing practice for materials and articles intended to come into contact with food.

Specific measures are found for some types of materials.

\section{Active and intelligent packaging}

- Regulation EC 450/2009 on active and intelligent materials and articles intended to come into contact with food.

\section{Plastic}

- Regulation EU 10/2011 on plastic materials and articles intended to come into contact with food.

- Regulation EC 282/2008 on recycled plastic materials and articles intended to come into contact with foods.

- Regulation EU 284/2011 laying down specific conditions and detailed procedures for the import of polyamide and melamine plastic kitchenware originating in or consigned from the People's Republic of China and Hong Kong Special Administrative Region, China. 


\section{Other materials}

- Regulation EU 321/2011 as regards the restriction of use of Bisphenol A in plastic infant feeding bottles.

- Directive 2007/42/EC relating to materials and articles made of regenerated cellulose film intended to come into contact with foodstuffs.

- Directive 84/500/EEC on the approximation of the laws of the Member States relating to ceramic articles intended to come into contact with foodstuffs.

- Regulation 1895/2005/EC on the restriction of use of certain epoxy derivatives in materials and articles intended to come into contact with food.

- Directive 93/11/EEC concerning the release, of the N-nitrosamines and $\mathrm{N}$-nitrosatable substances from elastomer or rubber teats and soothers.

An overview of the EU and Nordic legislation on FCM can be found on the webpages below, including implemented directives. An overview of the EU legislation is also available on the Commission webpage:

\section{EU Commission}

- http://ec.europa.eu/food/food/chemicalsafety/foodcontact/legisl_li st_en.htm

- Database: https://webgate.ec.europa.eu/sanco_foods/main/?sector= FCM\&auth=SANCAS

\section{Danish Veterinary and Food Administration}

- http://www.foedevarestyrelsen.dk/Leksikon/Sider/Emballage-ogf\%C3\%B8devarekontaktmaterialer.aspx

\section{Finnish Food Safety Authority}

- http://www.evira.fi

\section{The Icelandic Food and Veterinary Authority}

- http://mast.is/matvaeli/snertiefni-matvaela/

\section{Norwegian Food Safety Authority}

- http://www.mattilsynet.no/mat_og_vann/uonskede_stofferimaten/ matkontaktmaterialer/

\section{National Food Agency Sweden}

- http://www.slv.se 


\section{Other legislation relevant for food contact materials}

- EU Food Law: Regulation (EC) 178/2002 laying down general principles and requirements of food law, establishing the European Food Safety Authority and procedures of food safety.

- EU Official control: Regulation (EC) 882/2004 on official controls performed to ensure the verification of compliance with feed and food law, animal health and animal welfare rules.

- EU Hygiene: Regulation (EC) 852/2004 on the hygiene of foodstuffs.

- EU Food additives: http://ec.europa.eu/food/food/chemicalsafety/ additives/index_en.htm

- Database: https://webgate.ec.europa.eu/sanco_foods/main/ ?sector=FAD

- EU Food flavours: http://ec.europa.eu/food/food/chemicalsafety/ flavouring/index_en.htm

- Database: https://webgate.ec.europa.eu/sanco_foods/main/ ?sector=FFL\&auth=SANCAS

\section{Risk assessment}

EU FCM risk assessment: EFSA, Panel on Food Contact Materials, Enzymes, Flavourings and Processing Aids, CEF panel:

- http://www.efsa.europa.eu/en/panels/fip.htm

\section{Guidance documents}

Metals and alloys: Council of Europe (2013): Metals and alloys used in food contact materials and articles. A practical guide for manufactures and regulators. Committee of experts on packaing materials for food and pharmaceutical products. (P-SC-EMB) 1-215.

\section{Good manufacturing practice}

Food contact materials: Printing inks, Nordic Publication:

- http://dx.doi.org/10.6027/TN2012-521

Guidelines for the application of the regulation (EC) 2023/2006 to the supply chain of materials and articles intended to come into contact with food (Italian guideline, in English, http://www.iss.it/binary/publ/cont/ 11_37_web.pdf). 



\section{Annex II: Analytical testing}

This Annex addresses principles in migration/release testing of FCMs composed of metals and alloys, but does not list specific methods.

\section{Documenting compliance with guidance limits}

The general principles for compliance testing of plastics can be applied for metallic items as well. For plastics, compliance can be documented by worst case calculations based on knowledge of the composition of the material or migration/release tests with food or simulants. Results from migration/release testing with food prevail over results from tests with simulants. So, if analyses are available with the food itself and also in simulants, the results from analysis with food will be considered as documentation for compliance. In this Nordic guidance, it is suggested to follow the same principle, as this enables the authorities to analyse and control imported pre-packed food. However, background levels of metals in food should be accounted for.

Metals and impurities likely to be present in significant amounts in the final FCM should be considered, when documenting compliance.

\section{Requirements for sampling and analysis in official control}

Regulation $882 / 2004$ on control specifies that sampling must be performed and samples must be handled in such a way as to guarantee both their legal and analytical validity. The Member States shall ensure that the equipment and methodologies applied are adequate for measuring the limit values stated in EU or national legislation. For methods of analysis the regulation on control requests the following performance criteria to be considered: accuracy, applicability (matrix and concentration range), limit of detection (LOD), limit of quantification (LOQ), precision, repeatability, reproducibility, recovery, selectivity and sensitivity.

For lead, cadmium, mercury and inorganic tin in food, regulation $333 / 2007$ lays down provisions for methods of sampling and analysis.

These principles which must be applied in the official control are also recommended for in-house control. 


\section{Migration/release testing}

Reasonable worst-case conditions should be mimicked when testing migration/release from FCMs. For FCMs based on metals and alloys this mean that $\mathrm{pH}$, salt, acid, fat and alcohol content of food or simulants should be considered carefully. Additionally, the presence of corrosion accelerators, like sulphur dioxide and nitrate should be taken into account. Other important factors to consider are storage time, temperature, e.g. thermal processing when filled, and residual oxygen in a closed container as oxygen might enhance the release of iron, aluminium and tin.

For canned food testing of the food at the end of shelf life is recommended. When this is not possible, accelerated tests like the ones specified for plastics in regulation 10/2011 can be applied. It should be noted that the initial concentration of metals in the food should be known, when tests with food are undertaken. Simulants are only recommended, when testing with food is not technically or practically possible. The Council of Europe suggests the use of artificial tap water and citric acid as simulants for migration/release testing of metals and alloys.

Instructions of use should be followed, e.g. coffee machines should be decalcified before release is tested. However, physical changes of the material must not occur.

Items that cannot be filled or put into simulants as they are, must be cut into smaller pieces for testing. When doing so it is important to consider abrasion, e.g. edges might need some time before testing, so that a passive layer can reform. Also, it should be considered if all parts of the item will come into contact with food. The exterior of a can or a lid will not under foreseeable use come into contact with the food. Therefore, it is difficult to argue that there is a health concern if the release originates from the exterior. For items where the surface area needs to be determined, e.g. a whisk, the Council of Europe has suggested to determine the envelope volume. This method differs from the method suggested for plastic FCM.

\section{Analytical methods}

There are various analytical methods available for the determination of metals. The most modern method is ICP-MS, Inductively Coupled Plasma Mass Spectrometry. This method has in many countries replaced the older AAS method, Atomic Absorption Spectrometry.

The main advantages of ICP-MS compared to AAS are improved sensitivity, resulting in lower detection limits, and the capability to determine several elements in the same run, i.e. multielement analysis. However, the purchase and running costs of an ICP-MS equipment is higher compared to AAS. Therefore, some migration/release test mights have 
been made with the less sensitive AAS method. For that reason, attention should be paid to the detection limit of the method used. Typically, these are higher for AAS methods compared to ICP-MS methods.

\section{Guideline from the Council of Europe}

Many of the above suggestions for testing FCM composed of metals and alloys have been taken from the Council of Europe guideline. If needed, we refer to this guideline for further details on analytical testing. 



\title{
Annex III:
}

\section{Alloys}

\begin{abstract}
Alloy
Metallic substance composed of two or more elements, as either a compound or a solution. Ordinarily, the components of alloys are metals, although carbon, a nonmetal, is an essential constituent of steel.
\end{abstract}

\section{Brass}

An alloy of copper and zinc, of historical and enduring importance because of its hardness and workability. The earliest brass, called calamine brass, was probably made by reduction of mixtures of zinc ores and copper ores.

\section{Bronze}

An alloy traditionally composed of copper and tin. Bronze is of exceptional historical interest and still finds wide applications. The proportions of copper and tin vary widely (e.g. from 67 to 95\% for copper). Some modern bronze alloys contain no tin at all, substituting with other metals such as aluminium, manganese and even zinc.

\section{Cast iron}

An alloy of iron that contains 2 to $4 \%$ carbon, along with varying amounts of silicon, manganese and traces of impurities such as sulfur and phosphorus. It is made by reducing iron ore in a blast furnace.

\section{German silver}

Now known as nickel silver. It contains $10-30 \%$ nickel mixed with copper and zinc. This alloy is a typical base for silver-plated ware.

\section{Stainless steel}

Stainless steels are a family of over 200 iron-carbon-chromium alloys usually containing 10 to $30 \%$ chromium. Stainless steels are also known as inox steel or inox from French "inoxydable". In conjunction with low carbon contents, chromium imparts remarkable resistance to corrosion and heat. The different types of stainless steels have different technical properties. 


\section{Surface coating}

Thin films which are functional and often decorative. Surface coatings include paints, drying oils and varnishes, synthetic clear coatings and other products whose primary function is to protect the surface of an object from the near environment.

\section{Stainless steel: Qualities and maintenance}

Stainless steel is a widely used material in the food industry. In general it has a hard, smooth surface which is easy to clean and is considered to be resistant to corrosion. However, corrosion can occur especially when stainless steel is exposed to a combination of wear, acid and salty food. Also, chlorine used for the sanitizing of equipment has a corrosive effect on stainless steel.

Stainless steel differs from carbon steel by the amount of chromium present. Unprotected carbon steel rusts readily when exposed to air and moisture. This iron oxide film, the rust, is active and accelerates corrosion by forming more iron oxide, and due to the greater volume of the iron oxide this tends to flake and fall away. Stainless steels contain sufficient chromium to form a passive film of chromium oxide, which prevents further surface corrosion by blocking oxygen diffusion to the steel surface. Also, corrosion is being blocked from spreading from the surface into the metal's internal structure. Due to the similar size, the steel and oxide ions bond very strongly and remain attached to the surface.

Stainless steels are a family of over 200 iron-carbon-chromium alloys. They contain a maximum of $1.2 \%$ carbon and a minimum of $10.5 \%$ chromium. Other elements present in stainless steel are nickel, molybdenum, nitrogen and copper. 


\begin{tabular}{|c|c|c|c|c|c|}
\hline Name & $\begin{array}{r}\text { Chromium } \\
\text { (\%) }\end{array}$ & $\begin{array}{r}\text { Carbon } \\
(\%)\end{array}$ & $\begin{array}{r}\text { Nickel } \\
(\%)\end{array}$ & Characteristics & Examples of use \\
\hline $\begin{array}{l}\text { Martensitic } \\
\text { stainless steel }\end{array}$ & About 13 & Up to 1 & & $\begin{array}{l}\text { Least expensive. High } \\
\text { resistance to wear but low } \\
\text { resistance to aggressive } \\
\text { environments. Difficult to } \\
\text { form and weld, but very } \\
\text { hard and strong. }\end{array}$ & $\begin{array}{l}1,4125 \text { (AISI } 440 \text { C) used for pumps } \\
1,4021 \text { (AISI } 420 \text { ) used for knife blades. } \\
1,4116 \text { used for superior kitchen knives }\end{array}$ \\
\hline $\begin{array}{l}\text { Ferritic stain- } \\
\text { less steel }\end{array}$ & Up to 17 & $\begin{array}{r}\text { About } \\
0.05\end{array}$ & & Magnetic & $\begin{array}{l}\text { Dishwashers, refrigerators, pans. } \\
1,4510 \text { used for cooking unit worktop } \\
1,4509 \text { (AISI } 441 \text { ) used for heater and } \\
\text { burner components }\end{array}$ \\
\hline $\begin{array}{l}\text { Austenitic } \\
\text { stainless steel }\end{array}$ & 18 & & $8-12$ & $\begin{array}{l}\text { Better formability and } \\
\text { weldability. }\end{array}$ & $\begin{array}{l}\text { Most commonly used in food and } \\
\text { beverage industries. 1,4301 (AISI 304) } \\
\text { used for brewing vessels, kitchen } \\
\text { sinks, milk tanks. 1,4401 (AISI 316) } \\
\text { used for storage of wines, salty foods, } \\
\text { jam and other aggressive media. }\end{array}$ \\
\hline $\begin{array}{l}\text { Duplex steels } \\
\text { (austenitic- } \\
\text { ferritic steels) }\end{array}$ & $21-24$ & & $1-8$ & & $\begin{array}{l}\text { Very high resistance to corrosion by } \\
\text { saline solutions at high temperatures. }\end{array}$ \\
\hline
\end{tabular}

AISI refers to American Iron and Steel Institute.

The "grade" of stainless steel refers to its quality, durability and temperature resistance. The numbers $(18 / 8,18 / 10$, etc.) are the composition of the stainless steel and refer to the percent of chromium and nickel (respectively) in the product. Stainless steel is considered to be corrosion resistant. Nevertheless it releases low amounts of nickel and chromium. The release is highest in new food contact materials and decreases over time. The release from stainless steel into food is negligible compared with the natural contents of these elements in food, considering an average daily diet. 
Ved Stranden 18

DK-1061 Copenhagen K

www.norden.org

\section{Food contact materials - metals and alloys}

Metals and alloys are widely applied as food contact materials, e.g. as process equipment in the food industry and as household utensils. Therefore, they are a potential source of food contamination. Migration of substances from food contact materials to food must not occur in amounts that endanger human health. Relevant for food contact materials made from metals and alloys are the migration (release) of metals, both the main components and foreseen impurities.

In-house control based on a declaration of compliance, DoC, and supporting documentation at the producers and importers are important prerequisites to limit this contamination and to ensure compliance with the legislation. This is considered a general part of quality assurance, even though the European legislation does not specifically require a DoC for metals and alloys used as food contact materials.

This Nordic guideline gives a short overview of toxicology, analytical feasibility, legislation and guideline values for release of metals from food contact materials. Therefore, the guideline will be a useful tool for industry and official food inspectors.

TemaNord 2015:522

ISBN 978-92-893-4033-5 (PRINT)

ISBN 978-92-893-4034-2 (PDF)

ISBN 978-92-893-4035-9 (EPUB)

ISSN 0908-6692

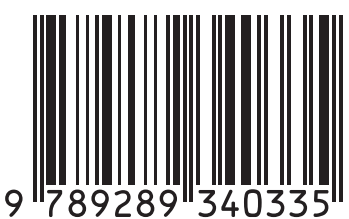

